\title{
The Elusive Archaeology of Kongo Urbanism: the Case of Kindoki, Mbanza Nsundi (Lower Congo, DRC)
}

\author{
Bernard Clist $^{1}$ - Els Cranshof ${ }^{1,3}$. \\ Gilles-Maurice de Schryver ${ }^{1,4}$ - Davy Herremans ${ }^{2}$. \\ Karlis Karklins $^{5} \cdot$ Igor Matonda $^{1,3} \cdot$ Caroline Polet $^{6}$. \\ Amanda Sengeløv ${ }^{2} \cdot$ Fanny Steyaert $^{7}$. \\ Charlotte Verhaeghe ${ }^{2} \cdot$ Koen Bostoen ${ }^{1}$
}

C Springer Science+Business Media New York 2015

\begin{abstract}
We present results, analyses, and an in-depth historical contextualization of the fieldwork undertaken in 2012 and 2013 at the Kindoki site in the Lower Congo (DRC). This site is linked to Mbanza Nsundi, one of the Kongo Kingdom's provincial capitals, which turns out to be archaeologically 'elusive'. Pinpointing its location proved to be particularly challenging. To this end, a historically informed survey methodology was applied that has rarely been implemented on such a scale in Central Africa before. We combined a strategy
\end{abstract}

Koen Bostoen

koen.bostoen@ugent.be

Bernard Clist

bernardolivier.clist@ugent.be

Els Cranshof

els.cranshof@ugent.be

Gilles-Maurice de Schryver

gillesmaurice.deschryver@ugent.be

Davy Herremans

davy.herremans@ugent.be

Karlis Karklins

karlis4444@gmail.com

Igor Matonda

igor.matondasakala@ugent.be

Caroline Polet

cpolet@naturalsciences.be

Amanda Sengeløv

asengelov@hotmail.com 
of systematic test pits with a large-scale 50-m grid approach. A cemetery was identified on Kindoki Hill with distinct but probably contemporaneous quarters of a sixteenthseventeenth-century settlement on both sides. The cemetery itself contains mainly eighteenth-century burials, in all likelihood of successive high-ranking Nsundi nobles, perhaps even of Nsundi rulers. The foreign, especially Portuguese, ceramics excavated on the hilltop and the hundreds of Venetian and likely Bavarian beads found in the graves are indicative of Mbanza Nsundi's connection to trade routes linking the Atlantic coast with the Pool region. The most striking discovery is that of a previously unknown type of comb-impressed pottery, from a pit with a calibrated radiocarbon date of AD 1294-1393 (at 2 sigma). This suggests that a settlement had been developing at Kindoki since at least the fourteenth century, which allows us, for the first time, to spatially bridge Kongo history and "prehistory." For the entire Lower Congo region, only three ${ }^{14} \mathrm{C}$ dates posterior to AD 1000 were available before the start of our project; 12 have been added for just Kindoki.

Résumé Nous présentons les résultats, les analyses et la contextualisation historique détaillée du travail de terrain entrepris en 2012 et 2013 sur le site de Kindoki situé au Bas-Congo (RDC). Ce site est associé à Mbanza Nsundi, l'une des capitales provinciales du royaume Kongo, qui s'est révélée 'élusive', c-à-d difficile à saisir archéologiquement. Localiser son emplacement s'est avéré être un vrai défi. Pour ce faire, nous avons développé une méthodologie de fouilles, basée sur des données historiques, qui n'avait pas encore vraiment été testée à cette échelle en Afrique Centrale. Nous avons appliqué une stratégie de terrain combinant des tranchées tests systématiques avec des carroyages à grande échelle de $50 \mathrm{~m}$. Sur la colline de Kindoki, un cimetière a été identifié avec de part et d'autre des quartiers distincts, probablement contemporains, témoignant d'une occupation aux $16^{\text {ème }}-17^{\text {ème }}$ siècles. Le cimetière luimême contient principalement des inhumations successives datées du $18^{\text {ème }}$ siècle, très probablement celles de nobles Nsundi de haut rang, peut-être même des dirigeants Nsundi. Les céramiques étrangères, principalement portugaises, découvertes au sommet de la colline et les centaines de perles originaires de Venise et probablement

Fanny Steyaert

fanny.steyaert@gmail.com

Charlotte Verhaeghe

lotte_verhaeghe@hotmail.com

1 KongoKing Research Group, Department of Languages and Cultures, Ghent University, Rozier 44, Ghent 9000, Belgium

2 Department of Archaeology, Ghent University, Ghent, Belgium

3 Centre de Recherches en Archéologie et Patrimoine, Université libre de Bruxelles, Brussels, Belgium

4 Department of African Languages, University of Pretoria, Pretoria, South Africa

5 Society of Bead Researchers, Ottawa, Canada

6 Department of Palaeontology, Royal Belgian Institute of Natural Sciences, Brussels, Belgium

7 Cabinet des Médailles, Bibliothèque royale de Bruxelles, Brussels, Belgium 
de la Bavière trouvées dans les tombes révèlent la connexion entre Mbanza Nsundi et les voies commerciales reliant la côte Atlantique avec la région du Pool. Une découverte très intéressante concerne un type de poterie décorée au peigne imprimé qui était inconnu à ce jour et provient d'une fosse dont la date radiocarbone calibrée est de 1294-1393 AD (à 2 sigma). Ceci suggère qu'une implantation s'est développée à Kindoki depuis au moins le $14^{\text {ème }}$ siècle et nous permet, pour la première fois, de rapprocher spatialement l'histoire et 'la préhistoire' kongo. Pour la région du BasCongo toute entière, seules trois dates ${ }^{14} \mathrm{C}$ postérieures à $1000 \mathrm{AD}$ étaient disponibles avant que ne débute notre projet. Nous disposons à présent de douze dates supplémentaires uniquement pour le site de Kindoki.

Keywords Central Africa $\cdot$ Kongo Kingdom · Urban archaeology $\cdot$ Cemetery $\cdot$ Pottery Swords $\cdot$ Beads

\section{Introduction}

It has been increasingly recognized that precolonial urban settlements across the African continent display a variety that is too great to be covered by a crossculturally valid definition (Fletcher 1995, p. 188, 1998; Connah 2001, pp. 291-296; Sinclair 2013, p. 692). Archaeologists have abandoned the idea that African urban origins are necessarily foreign, and stepped back from assessing African settlements along purely Eurocentric lines (LaViolette and Fleisher 2005, p. 327). One of the central aims of urban archaeology in Africa has become to record the material remains of Africa's culturally diverse urban experience. This endeavor is well underway in several parts of the continent, such as the Sahel and Guinean regions of West Africa (e.g., Connah 1975; Andah 1995; McIntosh 1999; McIntosh 2005; Monroe 2007), the Indian Ocean coast of East Africa (e.g., Chittick 1974, 1984; Fleisher 2010; Fleisher and Wynne-Jones 2012; LaViolette 2013), and Southern Africa (e.g., Huffman 2005; Pikirayi 2013; Schoeman 2013). Compared to these areas and in spite of some early pioneering research in its eastern periphery (e.g., Posnansky 1968), Central Africa is seriously lagging behind. Nevertheless, it could add considerably to our understanding of regional urban diversity in Africa. As in certain parts of Eastern and Southern Africa, it also hosts the "Bantu cities" (Coquery-Vidrovitch 2005, pp. 53-87) —among them, the capitals of several states in the Congo Basin and its environs (Connah 2001, pp. 263-265; de Maret 2013). In the Lower Congo region, the Kongo Kingdom is no doubt the most famous of a larger complex of mostly contemporaneous and culturally related polities, also including Loango and Tio (Vansina 1999, pp. 168-169). Kongo's central capital Mbanza Kongo or São Salvador-sometimes along with Loango's eponymous capital - is no doubt the most cited case of early urbanism in western Central Africa (Bairoch 1988, p. 391; Coquery-Vidrovitch 2005, pp. 77-81; Kusimba et al. 2006, p. 154; Freund 2007, pp. 8-9; Marcus and Sabloff 2008, pp. 235). According to CoqueryVidrovitch (2005, p. 77), it "was undoubtedly the only real city before the Portuguese arrived," i.e., before 1482. Later on, it was only seconded by the provincial capital of Mbanza Soyo, which was connected to Mpinda - an important ocean trade harbor just south of the Congo mouth - and had an estimated population of 30,000 in the eighteenth century. The size of Mbanza Kongo's population at its height, i.e., around the 
mid-seventeenth century, has been estimated at some 60,000 to 70,000 inhabitants (Thornton 1977). In spite of their political, cultural, and demographic importance, the archaeology of these urban Kongo settlements or mbanza is poorly developed. They have only been the subject of some preliminary archaeological work (Esteves 1989; Abranches 1991; Souindoula 1992), while the tentative reconstruction of their spatial structuring has been solely based on historical testimonies (Thornton 2000; de Maret 2002, 2006). The reason for this state of affairs becomes clear when one takes into account that the actual excavation of a mbanza site presents a particular problem: they are "elusive." Indeed, of the historical Kongo Kingdom's six main provinces, the location of only two mbanza is known today with some degree of certainty: Mbanza Kongo and Mbanza Soyo (Fig. 1).

To shed more light on these elusive cities, the systematic archaeological study of Kongo mbanza sites and their hinterlands is one of the core objectives of the interuniversity KongoKing project (http://kongoking.org/), which since 2012 has been carrying out interdisciplinary research on the origins and early history of the Kongo Kingdom. The team's archaeological research has so far focused on the Inkisi Valley in the eastern part of the Lower Congo Province of the DRC. This river basin hosted some important Kongo settlements, such as the capitals of the three major northern and eastern provinces: Mbata, Mpangu, and Nsundi (Thornton 1977, p. 523, 1983, p. 4; Hilton 1985, p. 7). In 2012 and 2013, extensive excavations were carried out on two sites, each linked with one of the former capitals of the Nsundi and Mbata provinces, i.e., respectively, Kindoki Hill overlooking present-day Mbanza Nsundi village (05 04'069 S; $\left.15^{\circ} 01^{\prime} 403 \mathrm{E}\right)$ and Ngongo Mbata (05 47'081 S; 15 07' 026 E) (Clist et al. 2013a, b, 2015). The functioning and spatial organization of these rural and more peripheral mbanza sites is even less understood than those of Mbanza Kongo and Mbanza Soyo. Nevertheless, they played a pivotal role in the kingdom's administrative centralization that had started long before the arrival of the first Portuguese in the late fifteenth century. They functioned as "nodes of political control" (Monroe 2013, p. 712) and tax collection hubs for the central powers in Mbanza Kongo (Coquery-Vidrovitch 2005, p. 81). Acquiring a better understanding of these provincial mbanza is thus crucial for a better comprehension of the rise of political complexity in the kingdom more generally. However, since a mbanza "got its distinctiveness from being a seat of government, a place of justice and a center of wealth - and not just from its size" (Thornton 2000, p. 67), its buildings and the way these were structured in space did not necessarily differ significantly from those in villages, even if it usually attracted a higher number of inhabitants (de Maret 2002, p. 7; Coquery-Vidrovitch 2005, p. 77). Under such conditions, the location in space of a historical mbanza site and the identification of its symbolic center may prove to be particularly challenging, even if archaeological methods have been developed elsewhere in Africa to tackle such problems (Connah 2008). Localizing the remains of a mbanza is all the more difficult when the site fell into oblivion after the kingdom's collapse and was also not described in great detail in the historical sources pertaining to the kingdom's heyday. Such is the case of Mbanza Nsundi, the capital of the northern Nsundi Province, on which this article focuses. Mbanza Nsundi was chosen as a case study as it illustrates the elusiveness of Kongo urban archaeology well, and allows us to put forward our methodology to deal with this elusiveness.

In the second part of the paper, we explain the significance of Mbanza Nsundi in the wider history of the Kongo Kingdom and why we have searched for its archaeological 


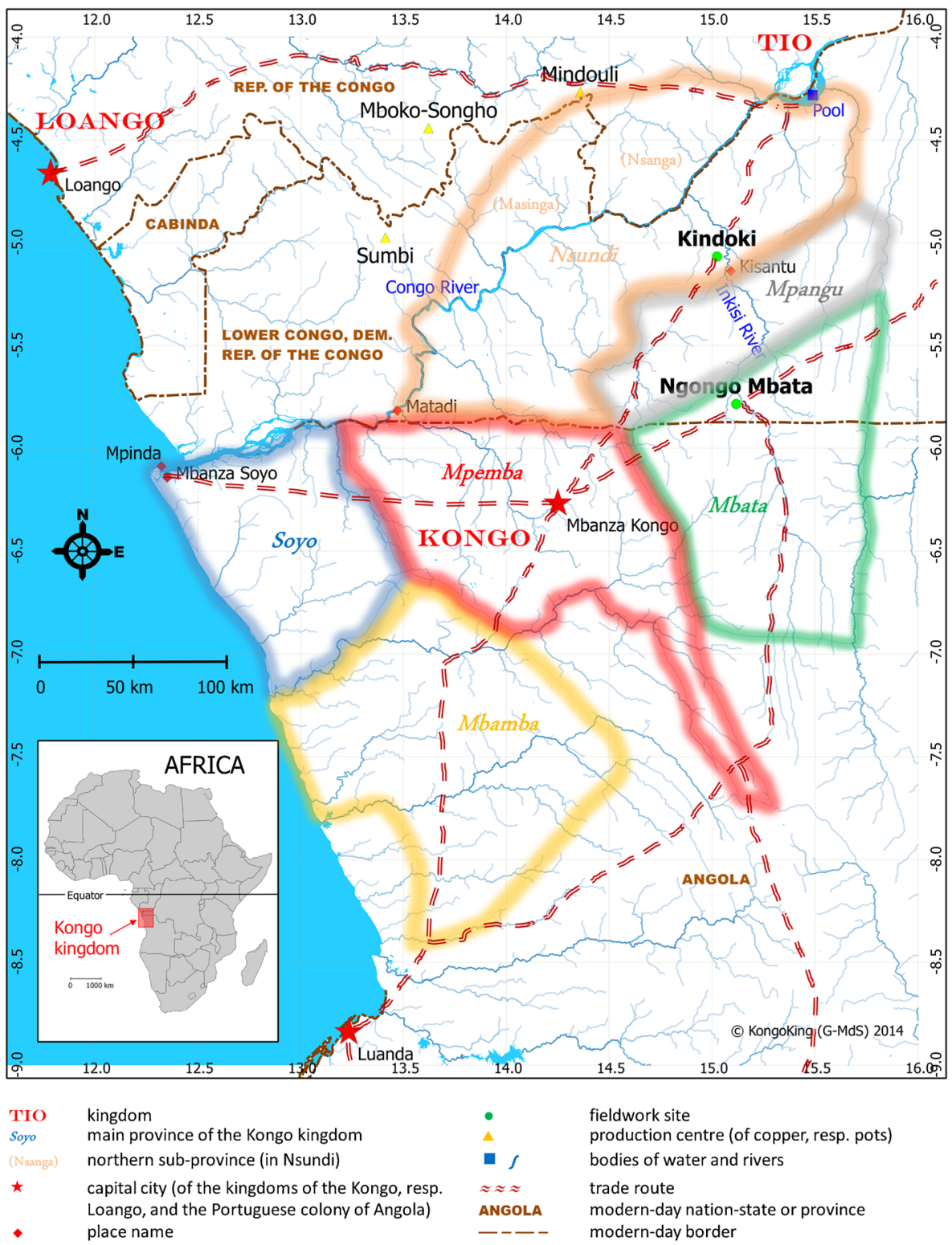

Fig. 1 The Kongo Kingdom's main provinces in the sixteenth-seventeenth centuries, with the two main mbanza indicated as well as the Kindoki and Ngongo Mbata archaeological sites. Source for the Kongo Kingdom's sixteenth-seventeenth-century main provinces: Randles (1968, p. 22). Sources for the sixteenthseventeenth-century trade routes in the region: Hilton $(1985$, p. 76$)$ and Vansina $(1994$, p. 264). Note that this map, which depicts the "main provinces" following Pigafetta (1591), is a simplification. The number of provinces and subprovinces as well as their sizes varied greatly with time. For a more detailed perspective, the reader is referred to the map in Thornton (1983, p. 40) for the year 1641, as well as the discussion in Thornton (2001) (image in full colour online)

vestiges on the Kindoki hilltop. We present the spatial characteristics of a Kongo mbanza as reflected in historical sources of the sixteenth to eighteenth centuries and 
how these led us to develop the historically informed survey strategy which we applied. Subsequently, a detailed discussion of the excavations that we carried out in 20122013 at Kindoki is presented, with special attention to the significance of the site within the regional archaeological context, the geological and natural setting, the excavation strategies deployed, the spatial distribution of artifacts found, the chronostratigraphical and cultural sequence of the hilltop, as well as the cemetery which the hilltop hosted. Then, Kindoki's archaeological record is assessed in the light of what we know on the history of Mbanza Nsundi, after which we present conclusions.

\section{Why Excavate Mbanza Nsundi/Kindoki?}

As capital of the Nsundi Province and residence of its governor, Mbanza Nsundi played a pivotal role in the integration of the kingdom's northern borderland into central administration.

In the first historical account of the Kongo, delivered by the Portuguese merchant Duarte Lopes in 1588, Nsundi is mentioned as the northernmost of the kingdom's six provinces: Bamba [= Mbamba], Sogno [= Soyo], Sundi [= Nsundi], Pango [= Mpangu], Batta [= Mbata], and Pemba [= Mpemba] (Pigafetta 1591, p. 25). It was one of the first territories truly conquered by Kongo leaders after the nuclear kingdom was formed through the voluntary federation of independent polities. An early expansion of the kingdom then took place in the Inkisi Valley through the conquest of the neighboring regions of Nsundi and Mpangu, which used to be independent polities (Thornton 2001, pp. 103-104, 114). Although the incorporation of both territories happened before historical times, i.e., anterior to the arrival of the Portuguese at the Congo mouth in 1482, their formerly autonomous status was still remembered a century later. When the Carmelite missionary Diego Del Santissimo Sacramento traveled in Nsundi in 1583, he learned that it had been a kingdom, though "small," i.e., "tãbien es otro Reyno, aunque pequeño" (Brásio 1954, p. 368; Thornton 2001, p. 104). Lopes also described Mpangu as a previously "free" kingdom, i.e., "La regione di Pango anticamente fu regno libero" (Pigafetta 1591, p. 36; Thornton 2001, p. 103). Nsundi's dominion at the end of the sixteenth century well exceeded the size it had before its subjugation. The province's hard-won expansion in the late fifteenth and early sixteenth centuries is well documented historically. King João I (ruled ?-1509), the first Kongo king known to the Portuguese, enlarged the province together with his son and later king Afonso I (ruled 1509-1543), who was the then Duke of Nsundi. They expanded Nsundi to the northeast along the south banks of the Congo and across by conquering Nsanga and Masinga. These territories became somehow subprovinces. Kongo conquest was met with fierce resistance that was crushed with the help of Portuguese troops (Hilton 1985, p. 55; Thornton 2001, p. 115). These "rebels" possibly adhered to the neighboring Tio Kingdom with which Kongo conflicted over control of the Mindouli and Mboko-Songho copper mines north of the Congo River, in the current-day Republic of the Congo (Fig. 1). Portuguese involvement in Kongo-Tio wars was no doubt prompted by this access to copper, along with the provision of war captives who fed the emerging slave trade (Hilton 1985, pp. 34, 59). This conquest also led to control over areas producing cloth and iron (Thornton 1982, p. 334). The incorporation of these new territories increased the administrative importance 
and complexity of Nsundi, which was reflected in the practice of assigning from then on its governance to the king's oldest son and most likely successor (Thornton 2001, p. 115).

Kongo and Tio interests did not only conflict in these copper-producing regions north of the Congo, but also further upstream in the area around the Pool, where the current-day capitals of Kinshasa and Brazzaville face each other. Both kingdoms strived for control over the Pool markets, which were one of the chief suppliers of foreign slaves to the Kongo until the late sixteenth century (Hilton 1985, p. 59; Heywood 2009, pp. 5, 14). For Kongo kings, the cooperation of Nsundi governors was pivotal in this pursuit. Afonso I, for instance, entrusted a kinsman with Nsundi governorship and offered him Portuguese assistance to ensure the constant supply of slaves, soon after he himself ascended to the throne of Kongo (Brásio 1952, pp. 294 296 - referring to an event from 1514; Hilton 1985, p. 59). Until at least the end of the sixteenth century, Nsundi dukes pacified the region and collected taxes on behalf of the central administration. This is exactly what the Nsundi governor was doing when the Italian Capuchin missionary Girolamo da Montesarchio and his fellow Bonaventura da Sorrento arrived in the province's capital in 1649: "Don Pedro, the Grand-Duke of Nsundi, son of the late King Don Alvaro, stayed on the other side of the Zaire river to subdue the people there and to collect tribute [...]" (our translation based on the original Italian text as edited by Piazza [1976, p. 178]). According to de Bouveignes and Cuvelier (1951, p. 36), da Montesarchio does not refer here to the Congo River, but to the "Zaire piccolo," also known as "Nzari aluelo" or "nzadi andwelo" (i.e., little river), which designated in those days the Inkisi River (Cuvelier 1946, p. 330; de Bouveignes and Cuvelier 1951, p. 135; Jadin 1964, p. 251; cf. also Bontinck 1970, p. 39). Da Montesarchio's Capuchin confrère Luca da Caltanisetta, who traveled in the Kongo in the closing decade of the sixteenth century, confirms repeatedly that the Duke of Nsundi regularly operated on the other side of this river, more precisely within the sphere of influence of the Ngobila, a Teke chief and renegade of the Tio Kingdom who resided south of the Pool (Bontinck 1970, pp. xii, 65, 66, 87).

If the Inkisi River indeed had to be crossed to go from Nsundi's capital to the lands of the Ngobila, Mbanza Nsundi must have been located west of the Inkisi. In his latesixteenth century description of the province, Duarte Lopes was the first to situate Mbanza Nsundi in the vicinity of a river: "near the border of the jurisdiction of Mpangu is the capital having the same name as the province, i.e., Nsundi, where the Governor lives and which is situated close to the falls of the river at one day to their south" (our translation based on the Italian original in Pigafetta [1591, p. 35]). The otherwise unspecified river could be the Congo itself. Falls on the Congo River are numerous in that part of the present-day Lower Congo Province known as the "Cataracts District." However, it could also be the Inkisi River whose lower reaches are characterized by three distinctive falls, i.e., the Mantumpu falls at the river mouth ( $8 \mathrm{~m}$ high), the Zongo falls $(58 \mathrm{~m})$ at $6 \mathrm{~km}$ from its confluence with the Congo, and the Sanga falls (24 m) at $10 \mathrm{~km}$ from the Zongo falls (Wamuini Lunkayilakio et al. 2010). The Zongo falls constitute a distinctive landscape element and are, up to today, a traveler's attraction situated some $50 \mathrm{~km}$ north of the Kindoki site. On the map depicting the Kongo Kingdom that accompanies the account of Lopes, an unnamed drawing of a "city" may be seen in the region labeled "Sunde," located south of the Congo River, and west of an unnamed tributary, itself west of the Berbela, or thus Inkisi River 
(Pigafetta 1591, map). The same location is found on the map of the entire African continent by Willem Janszoon (Blaeu) from 1608, as well as on the more detailed map of Congo and Angola by Joannes Jansson from 1650, where both the province and the city are named "Sunda." The latter map also depicts a "Cundi" on the west bank of the Coango/Berbela, with a "Sonan Cundi" further westward.

If Lopes' description remained vague on the location of Mbanza Nsundi, da Montesarchio situates it more clearly in the Congo-Inkisi confluence zone. In the account of his apostolic work in the Kongo between 1648 and 1668, he recurrently refers to the site of Nsundi's capital in approximate terms, but once with more exactitude when he relates a conflict between the Duke of Nsundi and the Duke of Mpangu, the son of the then king, which occurred in 1657: "[...] and he [the Duke of Nsundi] thought that the best solution would be to flee and not to combat the king's son, and thus he fled to the other side of the 'little Zaïre', a densely populated area also subjugated to him" (our translation based on the original Italian text as edited by Piazza [1976, p. 233]). In contrast to other episodes in his account where he associates Mbanza Nsundi with the hydronym Zaire tout court, he clearly mentions here "Zaire piccolo" alias the Inkisi River, which the Duke had to cross to seek refuge east of it. The implantation of Nsundi's capital west of the Inkisi was strategic. It was situated at the gateway to the copper-producing territories of Nsanga and Masinga, which Nsundi had started to capture since the late fifteenth century. Moreover, it bordered an important natural barrier on the vital trade route supplying Luanda and Mbanza Kongo with slaves from the Pool area, which Nsundi also had coveted since the early sixteenth century.

On the basis of the abovementioned sixteenth-seventeenth-century historical testimonies supplemented with more recent oral traditions, several twentieth-century scholars further narrowed the location of Mbanza Nsundi to the west of the Inkisi River in the neighborhood of current-day Kisantu. Van Wing (1921, p. 109) is of the opinion that toward the end of the sixteenth century, the ancient Duchy of Nsundi had its capital in "the corner formed by the Congo and the Inkisi," probably at the current location of Mbanza Nsundi. Cuvelier (1946, p. 349) is convinced that "[l]es données sont multiples pour localiser Mbanza Nsundi avec exactitude, à proximité de Bololo» ["the facts converge to situate Mbanza Nsundi with accuracy in the proximity of Bololo"], a claim which is reiterated in de Bouveignes and Cuvelier (1951, p. 33): «la capitale du Nsundi était située près de l'Inkisi, sur la rive occidentale, au nord du chemin de fer, près du village actuel de Mbanza Nsundi, non loin de Bololo" ["the capital of Nsundi was situated close to the Inkisi, on the west bank, north of the railway, close to the current village of Mbanza Nsundi, not far from Bololo"]. This view was also espoused by de Munck (1971, pp. 10, 41). The latter accompanied Pierre de Maret when he prospected the present-day village of Mbanza Nsundi in 1973. They took photographs of Kongo symbols of power that had been kept by local community members, such as a fragment of a large iron gong and an iron sword, as well as a small copper statue of the Virgin. De Maret was also shown the tomb of a former Duke of Nsundi or mwene Nsundi. According to Laman (1957, p. 138), the last mwene Nsundi would have been buried in 1835. The existence of this tomb on Kindoki Hill was reconfirmed when Bernard Clist interviewed local chiefs during a preparatory mission in May 2012. At that occasion, he could also photograph several other traditional power symbols kept by the chef de groupement, such as iron swords, anvils, a leopard skin, and a chief's stick, some of them allegedly removed from the abovementioned Duke's tomb. Oral testimonies gathered in 2012 also had it that an old church once stood near this tomb. 
The existence of a church in Mbanza Nsundi is indeed attested in several historical sources from the seventeenth century onwards (Cuvelier 1946, pp. 91ff., 218; de Bouveignes and Cuvelier 1951, p. 135; Cuvelier and Jadin 1954, pp. 394-395; Jadin 1964, pp. 202, 371, 1968, pp. 337, 433). According to Axelson (1970, p. 53), a church would already have been built in Mbanza Nsundi in 1495 when missionaries and the foremost baptized Kongo noblemen had to flee to Nsundi. However, this is not explicitly stated in the account of the sixteenth-century Portuguese chronicler João de Barros on the reign of Afonso I (Brásio 1952, pp. 141ff.), to which Axelson (1970, p. 295) refers. In a 1640 report to Pope Urban VIII, Francisco de Soveral does mention the existence of a parish church with a priest in the Duchy of Nsundi (Cuvelier and Jadin 1954, p. 509). In 1648, Bonaventura da Sorrento, Girolamo da Montesarchio, and Umile da San Felice settled in Mbanza Nsundi to found a Capuchin mission post. They built a hut for lodging and a chapel. Shortly after their arrival, the parish priest retired to Luanda and left the parish and its church to the care of the Capuchins (Saccardo 1982, p. 404). In her biography of William Holman Bentley, H.M. Bentley (1907, p. 100) mentions in passing a stone church in Mbanza Nsundi, which her late husband would have mentioned in a discussion with a local chief during his travels through the Manyanga region in the early 1880s. The existence of such a stone church in Nsundi's capital is not mentioned elsewhere.

These historical elements led the KongoKing team to carry out extensive excavations on the Kindoki hilltop, some 750 m north of the present Mbanza Nsundi village, with the aim to identify ducal graves as well as the old center of Nsundi's capital.

\section{Spatial Properties of a mbanza}

The excavation of a Kongo mbanza site requires an appropriate and historically informed strategy. Unfortunately, historical descriptions of Mbanza Nsundi are hardly informative on its architecture and spatial layout. From the historical data presented in the previous section, it can be deduced that from the late sixteenth century onwards, and possibly earlier, Nsundi's main capital was more or less permanently implanted on the Inkisi's west bank at about a day's walking distance from the falls near its confluence with the Congo. There are no indications of major shifts of its location, even if seventeenth-century chroniclers, such as da Montesarchio and da Caltanisetta, provide unmistakable evidence for the fact that the Duke of Nsundi regularly resided - and often for long periods - in the Pool area (de Bouveignes and Cuvelier 1951; Bontinck 1970; Piazza 1976). For reasons unclear, Jean Cuvelier associates this secondary residence and refuge in times of war with a place called Kimbongo, which would have been situated on a hill (Cuvelier 1946; de Bouveignes and Cuvelier 1951). Primary historical sources testifying to the presence of Nsundi dukes in the vicinity of the Pool neither mention this toponym, nor do they testify to the fact that Afonso I would have resided there when he was still Nsundi governor, as Cuvelier (1946, pp. 94-95) claims.

Since no detailed descriptions of Mbanza Nsundi's spatial organization are available, we had to rely on the description of other mbanza sites to develop our excavation strategy. The fact that these accounts largely concur from the fifteenth to eighteenth centuries allows us to extrapolate their features to Mbanza Nsundi. Different European chroniclers described provincial mbanza of the sixteenth to eighteenth centuries as expansive settlements centered around a symbolic core consisting of the duke's residence, the compounds 
of related nobility, a sacred wood with the ancestor's graves, and a plaza for ceremonial and judicial purposes (de Maret 2002, p. 7; Coquery-Vidrovitch 2005, p. 77).

The typical layout of a mbanza is well reflected in the description which Duarte Lopes provided of Mbanza Kongo where he lived from 1579 to 1583, at a time when Kongo's main capital had already undergone almost a century of Portuguese influence (Pigafetta 1591, p. 40):

Outside the walls which surround the king's household and the Portuguese city, many constructions belonging to various noblemen, each one occupying, without any order, the place he likes, so as to live close to the court. So it is not possible to estimate the size of this city outside of the two enclosures, as all the countryside is scattered with rural houses and palaces. Each nobleman, in his compound, is walled in like a village. [translation by de Maret (2002, p. 7)]

In 1648, the Italian Capuchin Giovanni Francesco Romano described Mbanza Kongo in very similar terms: "On the slope, all around the mountain, there are numerous residences and villas of important individuals. The top of the mountain consists of a very large plateau; that's where the city, which is very extensive, is built" (our translation based on the French translation by Bontinck (1964, p. 40) of the Italian original).

Such a spread-out plan was certainly not unique to Mbanza Kongo as evidenced by da Caltanissetta's informative description of Mbanza Nzonzo, a settlement situated east of the Inkisi River at a distance of eight walking days from Mbanza Nsundi:

In the evening [October 18, 1699], driven by my curiosity, I wanted to see with my own eyes the hills inhabited by the people of the mbanza and visit them so that no mistake could remain about them. I went to inspect them accompanied by my interpreter and many people, both ours and of Nzonzo. There were no less than fifteen hills, incredible to say, especially for black people; Yet I saw it and realized that this number was exact. The huts were not tightly packed one upon the other but at a certain distance. In the middle of the inhabited hills, there were others that were abandoned, making the mbanza more extensive. [...] In my opinion, it seems as if all huts were placed one near the other, they would occupy only seven good hills. [our translation based on the French translation by Bontinck (1970, p. 179) of the Italian original; see Rainero (1972, p. 358) for the original description]

This is perfectly in line with the description of Mbanza Soyo by da Caltanisetta's confrère Giacinto da Bologna, who lived there in the Capuchin mission from 1741 to 1747:

In my Soyo mission, situated on a large plain, I could from my post only see the residence of the prince and four or five other huts. [...] a vast land occupied by inhabitants; each of them with his family and slaves living either at a quarter of a mile, either at half a mile from his neighbors, the country in between being cultivated. Also some mbanza stretch out over as many as two leagues. [our translation based on the French translation by Nothomb (1931, p. 99) of the Italian original]

Unfortunately, no similar descriptions are available for Mbanza Nsundi. The only historical element suggesting that its layout was as outstretched as contemporary 
mbanza sites is the passage cited above from around 1657 by da Montesarchio, where he described how the Duke of Nsundi fled from his capital to seek shelter on the other side of the Inkisi. The episode continues as follows: "Due to his escape, the whole city fled, and not only the city but also all surrounding territories, in such a way, that for a good day of journey not a single person could be found" (our translation based on the original Italian text as edited by Piazza [1976, p. 233]). This suggests that Mbanza Nsundi was perhaps not so densely populated if everyone could flee, but that at least its range of immediate influence stretched quite far.

If Mbanza Nsundi had a similar layout as all other mbanza for which a description is available, we can assume that it was an extensive but scattered settlement with an archaeological signature that is not very different from that of a village. Below, a detailed explanation is given of the excavation strategy we developed to study the internal settlement structure of the Kindoki Hill site.

\section{Excavating Mbanza Nsundi/Kindoki}

\section{Regional Archaeological Context}

Late Iron Age archaeology in the Lower Congo region is poorly developed. Very telling in this respect is the fact that only three ${ }^{14} \mathrm{C}$ dates postdating AD 1000 were available before the start of the KongoKing project. The period between AD 600 and 1000 is nearly completely absent from the archaeological record, with only one single ${ }^{14} \mathrm{C}$ date (Clist 2012, p. 203). Since the start of the project, KongoKing has obtained 21 new ${ }^{14} \mathrm{C}$ dates relating to the Late Iron Age, 12 of which are for Kindoki and seven are published here for the first time.

With his pioneering article on the Stone Age of the Lower Congo region, Dupont (1887) determined the archaeological research agenda from which one did not depart until the Second World War ( $c f$. de Maret 1990b for a detailed overview of the history of archaeology in this region). Although the Belgian civil servant Verschaffel excavated two historical tombs on Mbanza Mbata Kuluzu in 1913 (Vandenhoute 1973, pp. 192193), true archaeological interest in the Late Iron Age only hesitatingly started in the 1940s, while the Lower Congo's Early Iron Age became the objective of dedicated excavations only in the 1970s, as part of an emerging international interest in the spread of Bantu-speaking agriculturalist village societies and iron metallurgy in Central Africa (e.g., Cahen 1981; Van Noten 1982; and de Maret 1986 for regional syntheses; see also Lanfranchi and Clist 1991). The innovative work of Maurits Bequaert, Georges Mortelmans, and Hendrik Van Moorsel, leading archaeologists in the last decades before and the first after Congolese independence, remains scientifically relevant for our ongoing KongoKing archaeological research. Bequaert (1940) reported on the excavations he carried out in 1938 in Ngongo Mbata, the first ever on a site immediately linked with Kongo history. His 1950-1952 archaeological mission in the Belgian Congo also provided new data on both the Early and Late Iron Age (Clist 1982). Mortelmans (1962) proposed the first seriation of mostly Late Iron Age ceramics on the basis of surface collections from the Dimba and Ngove caves in the heart of the Lower Congo Province. His classification of pottery groups remains a reference tool for archaeologists working in the region. Several pottery types excavated or surface collected by the KongoKing research team since 2012 can be attributed to one of the 
groups he distinguished. However, several others, of which some are discussed in this article, do not fit at all in his classification, showing the need for an up-to-date typology. Van Moorsel $(1948,1968)$ published several discoveries of pottery, most of them fitting within the timeframe of the Kongo Kingdom for which he had a genuine interest. Van Moorsel (1968, pp. 223-277) relied on historical data to interpret an archaeological site in present-day Kinshasa as the village of the Teke chief Ngobila, one of the main opponents of the Duke of Nsundi in the Pool area ( $c f$. supra). Further afield, in Angola, surveys were carried out in the 1960s and 1970s on some Late Iron Age stone fortifications, among others, for the ancient capital of the Huambo kingdom at Samissassa (Ervedosa 1980, pp. 197-220, 396-413).

Subsequent archaeological research relatable to the Kongo Kingdom had to await the 1980s when several scholars began to target the kingdom's archaeology through pilot studies of limited scope (Esteves 1989; Abranches 1991; Clist 1991, 2012; de Maret 2002, 2006; Heimlich 2010, 2013). Concurrently, new research contributed to a better understanding of the subregion's Iron Age (Lanfranchi and Pinçon 1988; de Maret 1990a; Denbow 1990; Kanimba Misago 1991; Lanfranchi 1991; Pinçon 1991; Dupré and Pinçon 1997; de Maret and Stainier 1999; Guttierez 2008; Da Silva Domingos 2009; Valdeyron and Da Silva Domingos 2009, 2012; Denbow 2012, 2014). Finally, the Iron Age of the Lower Congo region has been explored through the rich archaeological collections of the Royal Museum for Central Africa in Tervuren as part of several MA dissertations (de Maret 1972; Vandenhoute 1973; Clist 1982; Rochette 1989). A more detailed review of Late Iron Age archaeology in the southern part of the Republic of the Congo, the Lower Congo Province of the DRC, and northern Angola - with regard to both the period and the region in which the Kongo Kingdom arose - may be found in Clist (2012).

This is the state of the art of archaeological research in the Lower Congo on which the KongoKing team has been building since the start of its activities in 2012. Through an approach in which archaeology and historical linguistics are the main players, the research group aims at a more thorough study of the origins and early history of the Kongo Kingdom (De Kind et al. 2012; Bostoen et al. 2013; Clist et al. 2013a, b, 2015; Nikis et al. 2013; Bostoen and de Schryver 2015). The KongoKing team also attempts to systematically archive and digitize the exceptionally rich Kongo documentation of the last four centuries. It will be used to interpret historically the archaeological data from Kindoki discussed in this article.

\section{Geological and Natural Setting}

Kindoki Hill $\left(05^{\circ} 04^{\prime} 069 \mathrm{~S} ; 5^{\circ} 01^{\prime} 403 \mathrm{E}\right)$ lies some $10 \mathrm{~km}$ northwest of Kisantu, a small town on the National Road no. 1 between Kinshasa and Matadi and about $95 \mathrm{~km}$ southwest of the Congolese capital as the crow flies. The geological substrate of the Kindoki site is composed of calcareous schist of the Bangu unit. Its subsoil contains sands which are more or less clayey, light gray, ocher yellow, red, often with pebbles at the base (Ladmirant and Annaert 1970). Kindoki Hill measures $700 \mathrm{~m}$ along its eastwest axis and $450 \mathrm{~m}$ along its north-south axis; its maximum surface is 30 ha. The hilltop's surface and its immediate surroundings are mostly cultivated with manioc. Except on fallow fields subject to bush regeneration, nearly no trees are observed. A 
permanent river flows immediately south of Mbanza Nsundi village and seven water sources with a small outflow rate are dispersed around the Kindoki Hill. The natural stratigraphy on Kindoki Hill is shown in Fig. 2 which illustrates $5 \mathrm{~m}$ of the trenches excavated in 2012. A first dark gray humic sand (Munsell 10YR 5/1) is underlain by a light gray sand (Munsell 10YR 4/1) which overlies a yellowish sandy clay layer (Munsell 10YR $4 / 2$ to $5 / 3$ or 6/6). All refuse pits (units $5,23,28,58$ ) start from the humic layer and are very distinct from the hill's yellowish sandy clay layer, which has a thickness varying between $0.4 \mathrm{~m}$ (unit 5) and $0.8 \mathrm{~m}$ (pit in unit 58). The majority of the Iron Age artifacts occur in the upper $0.4 \mathrm{~m}$ of soil, but are found as deep as the upper $0.6 \mathrm{~m}$. Most archaeological material is included within the humic layer. Potsherds from the humic layer usually manifest a mixture of different types, but certain surfaces do contain relatively homogeneous material. Postdeposit perturbation is common at Kindoki, mainly due to the activity of termites (Odontotermes sp.), ants (Myrmicaria natalensis), ground squirrels (Xerus erythropus), and humans. While ground squirrels dig holes and tunnels to a depth of $1 \mathrm{~m}$, termites and ants bring up large volumes of soil, slowly burying artifacts in this way. Agricultural activity led to the homogenization of the hilltop's first $0.3 \mathrm{~m}$. A gently undulating surface due to hoeing is well visible in the stratigraphy presented in Fig. 2. We know from a 1953 aerial photograph that village huts, responsible for further soil perturbations, were present on the western and eastern part of the hill. Similar soil perturbations were observed by Schwartz and Lanfranchi (1990) in the region of Brazzaville.

\section{Excavation Strategy}

As discussed in the section "Spatial Properties of a mbanza," the archaeological signature of a mbanza site is not necessarily very distinct from that of a village. In order to identify such a signature, one could carry out physical and electronic subsurface prospections associated to large-scale spatial excavations, as has been done elsewhere in Africa to improve the archaeological visibility of ancient urbanism (Magnavita et al. 2006; Connah 2008). For logistic reasons, such subsurface surveys using magnetics or ground-penetrating radar have not been applied yet to the Kindoki Hill site. In order to study its internal settlement structure, we have limited ourselves for the time being to large-scale test excavations in conjunction with a careful analysis of

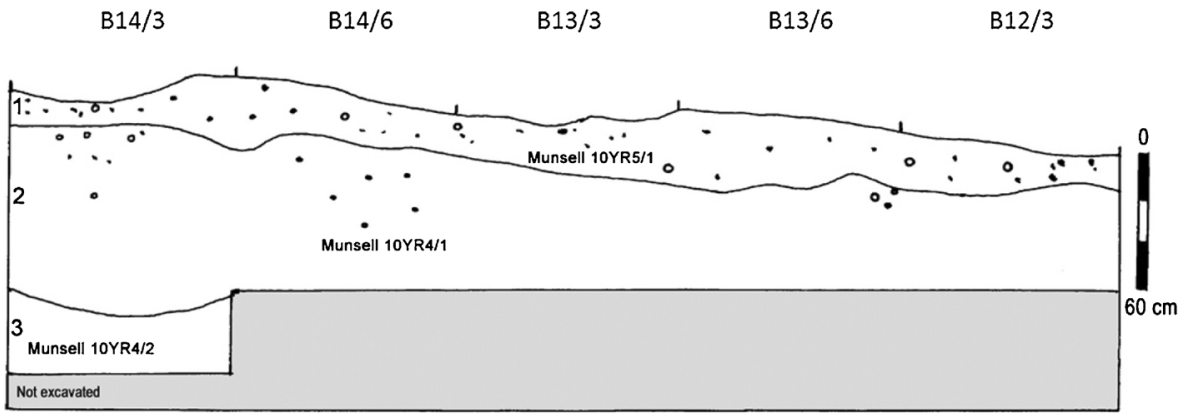

Fig. 2 General stratigraphy of the Kindoki hilltop: a dark gray humic layer heavily perturbed by modern tilling (1), and a light gray sandy clay layer (2), overlying the yellowish sandy clay of the hilltop (3). The Late Iron Age material is found in layers 1 and 2 
stratigraphy and local factors of environmental, anthropic, and biotic perturbation. The excavation strategy deployed for Kindoki differed from 2012 to 2013.

In July 2012, the objectives were to gain an overall idea of the chronology of Late Iron Age settlements on the Kindoki hilltop, to verify their stratigraphic integrity, and to locate the church mentioned in the historical sources as well as the dukes' cemetery remembered in local oral tradition. After surveying, no church was located but a small cemetery was indeed found, two of its tombs excavated, and four 1-m-wide test trenches were geographically oriented (north/east/south/west) and extended for $40 \mathrm{~m}$ (south), $20 \mathrm{~m}$ (west and north), and $11 \mathrm{~m}$ (east) while extending to a depth of $0.6 \mathrm{~m}$. Every $5 \mathrm{~m}$, the square was extended to a depth of $1 \mathrm{~m}$. All the work was carried out using 10-cm spits (Clist et al. 2013a).

In July 2013, the fieldwork specifically aimed at understanding the range of Late Iron Age occupations over the entire hilltop related, as outlined above, to the historical knowledge gathered on the layout of ancient mbanza (Clist et al. 2013b). After clearing vegetation along several 4-m-wide perpendicular axes (Fig. 3), excavations were conducted along a 700-m east-west axis and a 450-m north-south axis. We dug $1-\mathrm{m}^{2}$ quadrats following a $50-\mathrm{m}$ grid, resulting in a total of 60 units of $1 \mathrm{~m}^{2}$ each with an initial depth of $1 \mathrm{~m}$ (Fig. 4), using 20$\mathrm{cm}$ spits. Several units displayed archaeological features, such as refuse pits (Fig. 5), or high artifact densities, which extended either horizontally or vertically. The excavation then switched to $10-\mathrm{cm}$ spits in units 5 (three pits), 23 (two pits), 28 (one pit and one grave), and 58 (one pit). Stripping of $34 \mathrm{~m}^{2}$ of the Late Iron Age occupation layer next to unit 23 led to the further discovery of four pits. The cemetery area deviated from this strategy from the moment it was discovered (in 2012) because stones of the funerary cairns protruded from the earth, after which it was excavated extensively (in 2013). This systematic

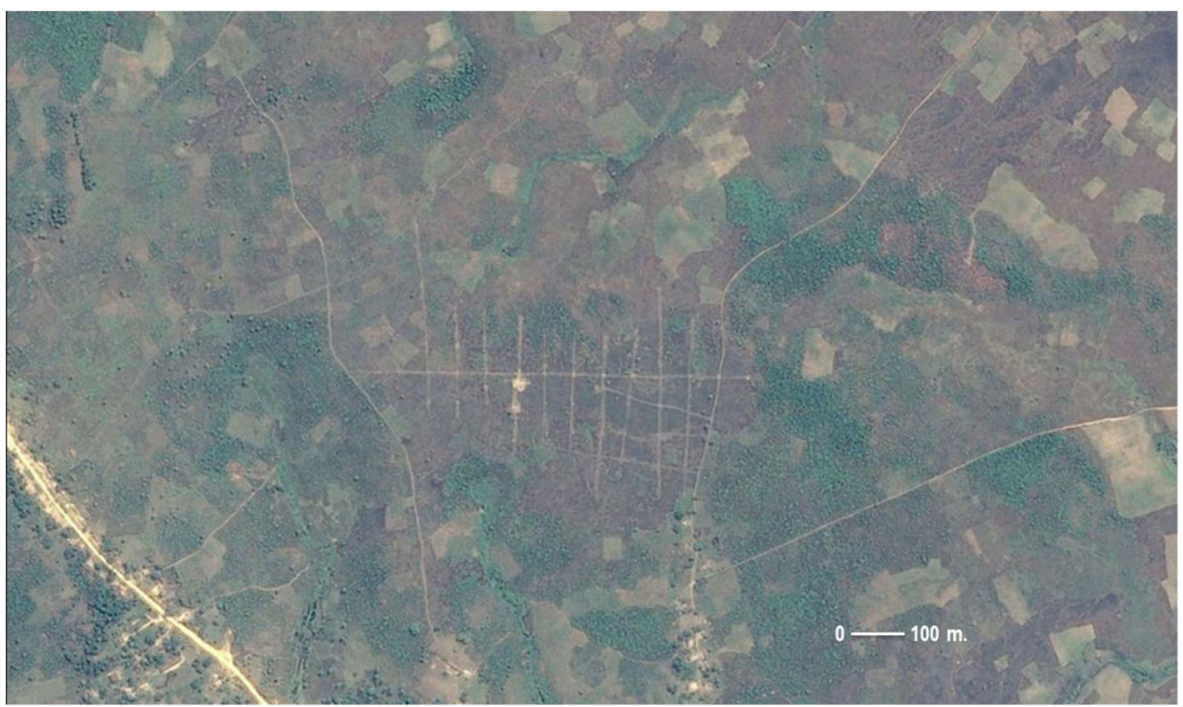

Fig. 3 Bird's eye view of Kindoki hilltop (Google Earth, August 4, 2013), with the positioning of the transects from which the vegetation was removed and in which units were set up (photo @ KongoKing) (image in full colour online) 


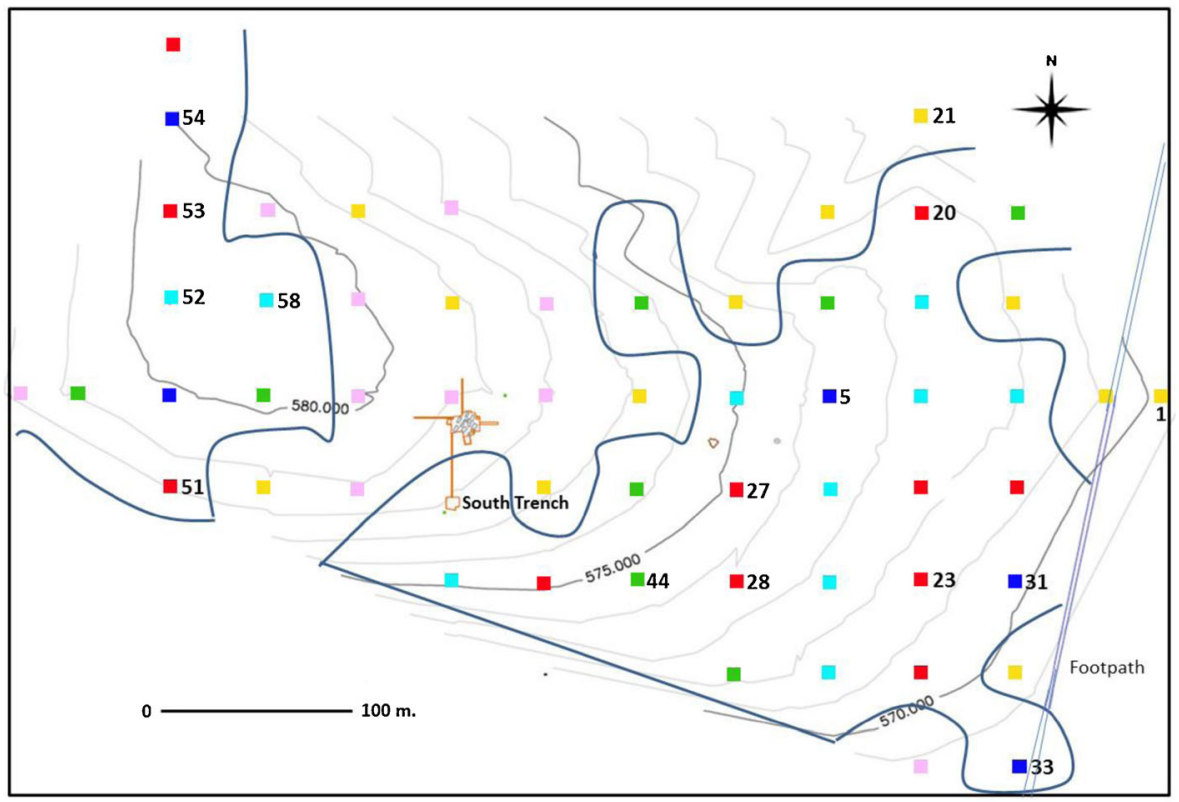

1-20: $=; 21-40:=; 41-60:=; 61-80:=; 81-100:=$; over 100: =

Fig. 4 Kindoki Hill: excavated cemetery area with north, east, south, and west trenches (2012 and 2013 excavations) and 50-m grid over the entire hill with Iron Age artifact densities for each of the 60 units (2013 excavation). The numbers of the units mentioned in the text are indicated, as well as the two main artifact concentrations of the sixteenth-eighteenth centuries. The density of potsherds per cubic meter is color-coded (image in full colour online)

and unbiased excavation strategy allowed us to open up a total of $279 \mathrm{~m}^{2}$ and provided us with a statistically representative image of the archaeological assemblages on this hill.

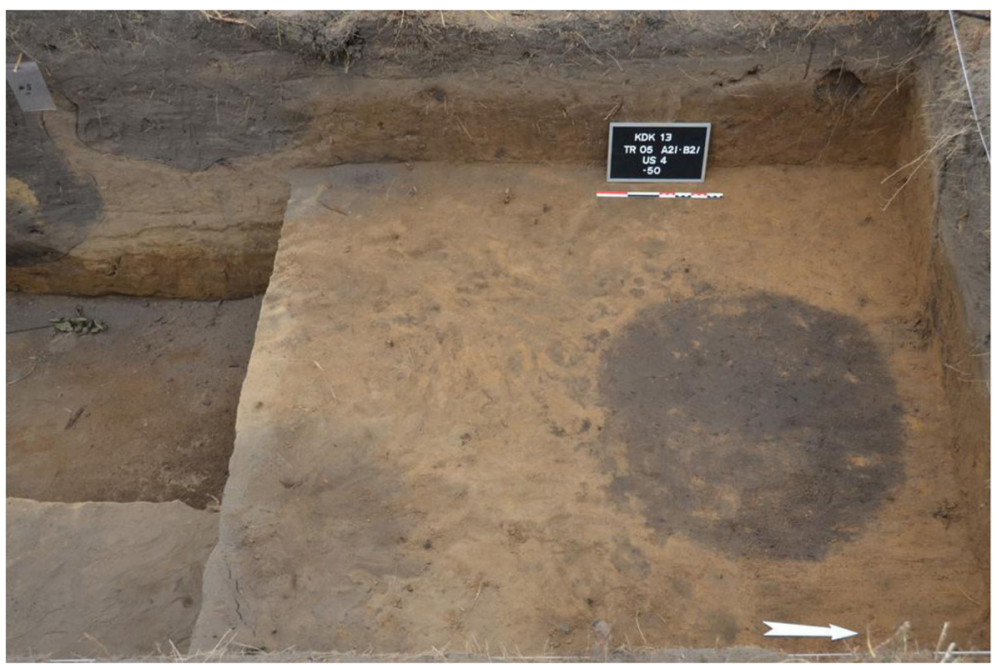

Fig. 5 Kindoki Hill: pits studied in unit 5. Excavation in progress of one with its contour clearly visible; note two others in the profile (photo CKongoKing) 
No other former mbanza site had been studied on such a large scale, except for the Ngongo Mbata hilltop where we applied a similar strategy (Clist et al. 2013b, 2015). Prior to our fieldwork, only test excavations of a few square meters had been carried out on contemporary and spatially similar archaeological sites in the region, such as Mashita Mbanza in the Bandundu Province (de Maret and Clist 1985; Pierot 1987) and Kingabwa in Kinshasa (Van Moorsel 1968; Cahen 1981). The only excavation where one single surface (of about $63.5 \mathrm{~m}^{2}$ ) was uncovered is the one directed by Daniel Cahen at Gombe Point, Kinshasa (de Maret and Stainier 1999, p. 477).

\section{Spatial Distribution of Artifacts}

A deep test trench of $2 \mathrm{~m}^{2}$ was opened southwest of the cemetery sector discussed below (squares A1-1/4 and A2-1/4). At $-2.65 \mathrm{~m}$ a core, several blocks and a few large flakes of jasper were found (= Stone Age 1). At the current stage of research, it is impossible to know whether this small sample of artifacts dates back to the Late or Middle Stone Age, but it indicates that hunter-gatherers once occupied the hill well before the start of the Iron Age.

Mapping the density of all Iron Age artifacts found on the hill clearly shows two areas with higher levels of domestic refuse on opposite sides of the excavated cemetery (Fig. 4). Judging from the artifacts they contained, both areas relate to the same time period (sixteenth-seventeenth centuries) and can be considered as two distinct, but probably contemporaneous quarters of the same settlement. More recent pottery (Fig. 6) is clearly concentrated on the eastern end of the hill and absent from the other

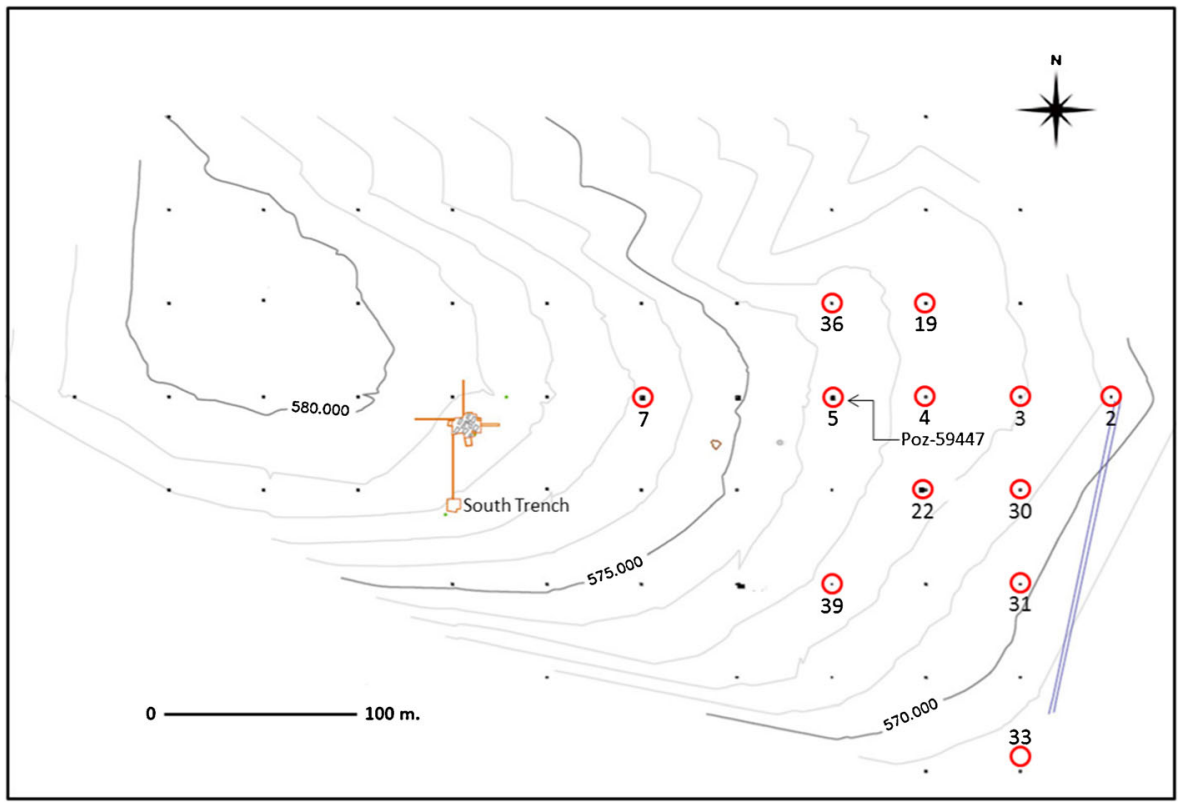

Fig. 6 Kindoki Hill: distribution of undecorated potsherds of the "Lemfu type," probably nineteenthtwentieth centuries. The numbers of the units where the material was found are indicated (image in full colour online) 
areas. Such is also the case with the very distinctive comb-impressed pottery (Figs. 7 and $12 \mathrm{a}[1])$. In units $1,3,4,7,12,18,22,24,44,51,53$, and 54 , only a few potsherds of this pottery were found in the upper $0.4 \mathrm{~m}$ of soil, often mixed with other types of pottery. Units 20,21, 23, and 28, all situated in the eastern part of the hill, yielded concentrations of comb-impressed material. They were found principally at $0.4-0.6 \mathrm{~m}$ indicating that this pottery type was originally deposited at this depth.

The few recovered European potsherds (Fig. 8) do not show any specific spatial concentration. They are also scattered in very low densities throughout the excavations (Table 1 and Fig. 9). Table 1 shows that Portuguese imports produced between the late sixteenth and late seventeenth centuries constitute the majority of foreign ceramics found at Kindoki (Newstead 2008; Casimiro 2011). Some English industrially produced wares date to the late eighteenth century (Walford and Massey 2007). A similar temporal pattern has been observed at the Ngongo Mbata site, some $70 \mathrm{~km}$ further south in the Inkisi Valley (Clist et al. 2015).

Kindoki Hill contains very few traces of iron slag. The slag is dispersed without any clear locus of activity suggesting that no extensive iron working happened on site (Fig. 10). An as yet unexcavated smelting area with a high concentration of iron slag and at least one furnace, which could be the hilltop's iron production quarter, has been located $600 \mathrm{~m}$ to the east of the excavated area.

The vertical dispersal of the archaeological material (outside of the pits) is limited to the upper $0.6 \mathrm{~m}$ (Fig. 11). In units 20, 21, and 31, the high density of artifacts at two different depths separated one from the other by sterile or very low density levels

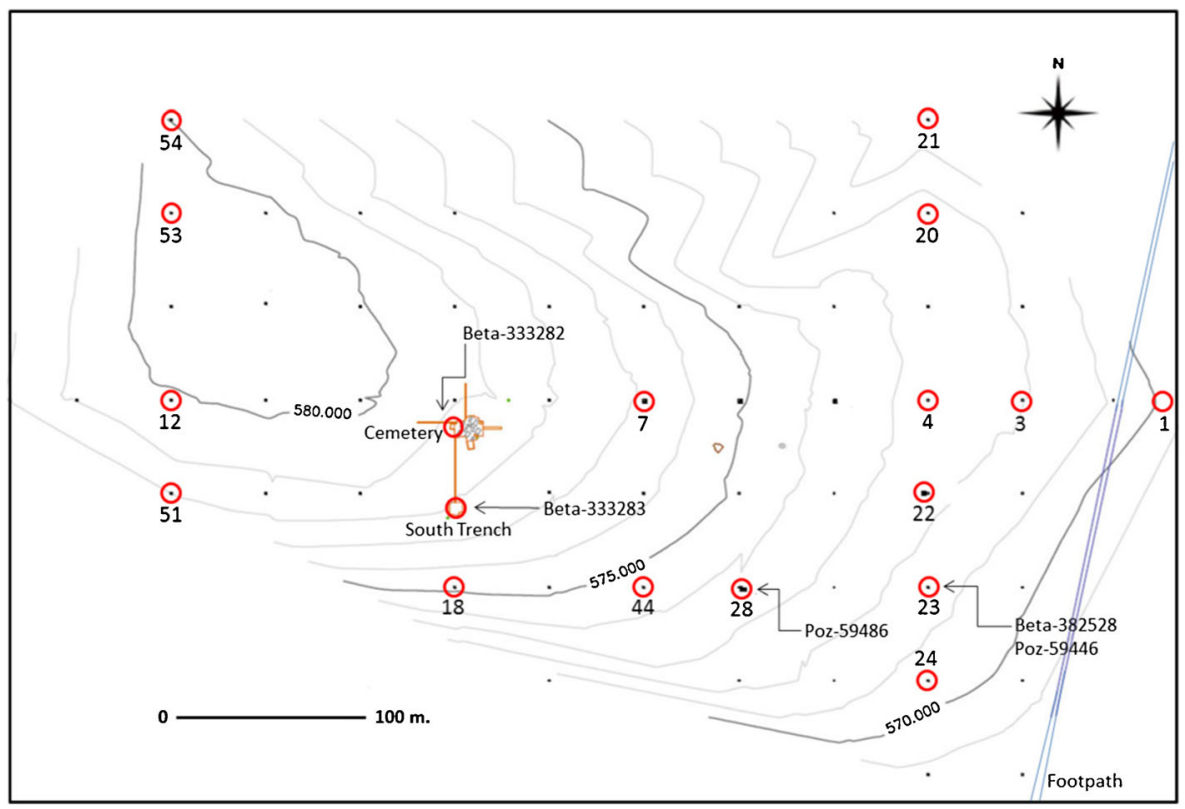

Fig. 7 Kindoki Hill: distribution of comb-impressed potsherds and associated ${ }^{14} \mathrm{C}$ dates. Concentrations of this distinctive pottery were only discovered in units 20,21, 23, and 28 (image in full colour online) 

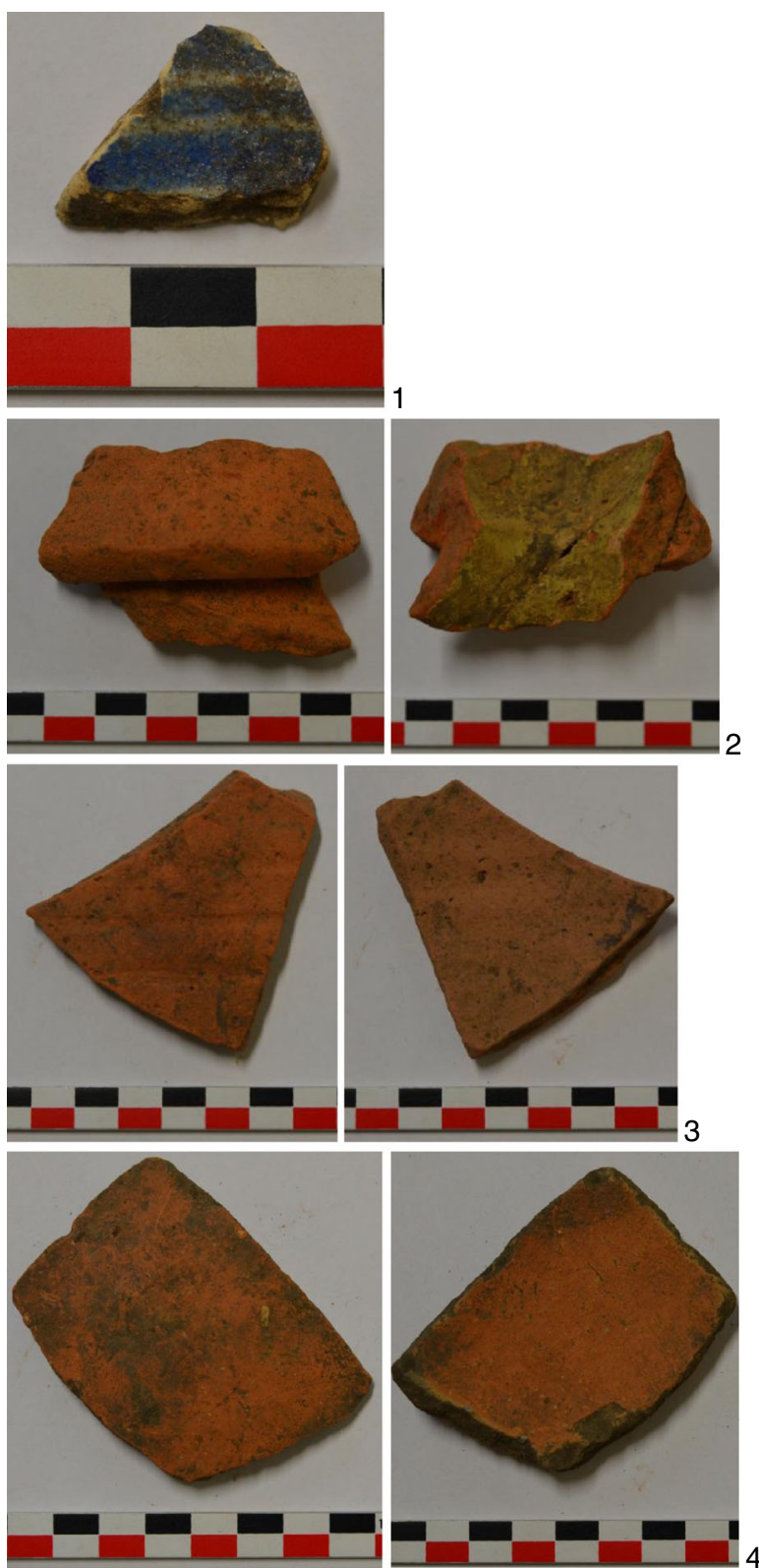

Fig. 8 Some of the Portuguese potsherds found at Kindoki: 1 tin glazed, unit 23, square E2, $-0.2 /-0.4 \mathrm{~m}$, seventeenth century. 2 Redware, unit $1,0 /-0.2 \mathrm{~m}$, second half of the sixteenth-first half of the seventeenth centuries. 3 Redware, unit 54, square A1, $-0.2 /-0.3 \mathrm{~m}$. 4 Redware, unit 31 , square $\mathrm{A} 1,-0.6 /-0.7 \mathrm{~m}$ (photo (CKongoKing)

suggests two separate Iron Age levels, i.e., one at around $0.4 \mathrm{~m}$ and one at around $0.6 \mathrm{~m}$. In other units (e.g., units 51-54), we found only a single concentration at around $0.6 \mathrm{~m}$ (Fig. 11). The typical artifacts are illustrated in Fig. 12. 
Table 1 Relative dates for the Kindoki site from European pottery imports

\begin{tabular}{|c|c|c|c|c|}
\hline Unit and square & Layer & Category & Production date & Origin \\
\hline Unit 1 & $0 /-0.2 \mathrm{~m}$ & Redware & $\begin{array}{l}\text { Second half of the } 16 \text { th century/first } \\
\text { half of the } 17 \text { th century }\end{array}$ & $\mathrm{P}$ \\
\hline Unit 5, A1 & $\begin{array}{l}-0.2 / \\
\quad-0.4 \mathrm{~m}\end{array}$ & Tin glazed & End of the 18 th century & $\mathrm{E}$ \\
\hline Unit 5, A1 & $\begin{array}{l}-0.5 / \\
-0.6 \mathrm{~m}\end{array}$ & Redware & $?$ & $\mathrm{P}$ \\
\hline Unit 5, B2 & $0 /-0.2 \mathrm{~m}$ & Redware & $?$ & $\mathrm{P}$ \\
\hline Unit $17, \mathrm{~B} 1$ & $\begin{array}{l}-0.1 / \\
-0.2 \mathrm{~m}\end{array}$ & Redware & $?$ & $\mathrm{P}$ \\
\hline Unit $18, \mathrm{~A} 1$ & $0 /-0.2 \mathrm{~m}$ & Redware & $?$ & $\mathrm{P}$ \\
\hline Unit 20, A1 & Surface & Redware & $?$ & $\mathrm{P}$ \\
\hline Unit $21, \mathrm{~A} 1$ & $\begin{array}{l}-0.2 / \\
-0.4 \mathrm{~m}\end{array}$ & Redware & $?$ & $\mathrm{P}$ \\
\hline Unit 21, B2 & $0 /-0.1 \mathrm{~m}$ & Redware & $?$ & $\mathrm{P}$ \\
\hline Unit 23, B1 & $0 /-0.2 \mathrm{~m}$ & Redware & $?$ & $\mathrm{P}$ \\
\hline Unit 23, E2 & $\begin{array}{l}-0.2 / \\
\quad-0.4 \mathrm{~m}\end{array}$ & Tin glazed & 17 th century & $\mathrm{P}$ \\
\hline Unit 28, B1 & $\begin{array}{l}-0.6 / \\
-0.7 \mathrm{~m}\end{array}$ & Redware & $?$ & $\mathrm{P}$ \\
\hline Unit 31, A1 & $\begin{array}{l}-0.6 / \\
-0.7 \mathrm{~m}\end{array}$ & Redware & $?$ & $\mathrm{P}$ \\
\hline Unit 32, A1 & $\begin{array}{l}-0.4 / \\
-0.5 \mathrm{~m}\end{array}$ & Redware & $?$ & $\mathrm{P}$ \\
\hline Unit 34, A1 & $\begin{array}{l}-0.2 / \\
-0.4 \mathrm{~m}\end{array}$ & Redware & $?$ & $\mathrm{P}$ \\
\hline Unit 39 , A1 & $0 /-0.2 \mathrm{~m}$ & Redware & $?$ & $\mathrm{P}$ \\
\hline Unit 42, A1 & $\begin{array}{l}-0.2 / \\
\quad-0.4 \mathrm{~m}\end{array}$ & Tin glazed & $?$ & $\mathrm{P}$ \\
\hline Unit 43, B1 & $0 /-0.2 \mathrm{~m}$ & Redware & $?$ & $\mathrm{P}$ \\
\hline Unit 54, A1 & $\begin{array}{l}-0.2 / \\
-0.3 \mathrm{~m}\end{array}$ & Redware & $?$ & $\mathrm{P}$ \\
\hline Unit 59, A1 & $\begin{array}{l}-0.2 / \\
-0.4 \mathrm{~m}\end{array}$ & Redware & $?$ & $\mathrm{P}$ \\
\hline
\end{tabular}

$P$ Portugal, $E$ England

\section{Chronostratigraphical and Cultural Sequence}

Twelve radiocarbon dates have been produced by the Beta Analytic Laboratory in Florida (USA) and the Poznań Radiocarbon Laboratory (Poland) from charcoal samples following the AMS method. By jointly considering stratigraphy, position of dated samples, radiocarbon dates, and the required calibration (Fig. 13a), the general picture as summarized in Table 2 and Fig. $13 \mathrm{~b}$ can be proposed.

The oldest ${ }^{14} \mathrm{C}$ date comes from the lowest level of the pit discovered in unit 28 (Poz-59486). Unlike the upper $0.6 \mathrm{~m}$ of soil above the pit which contained artifacts of 


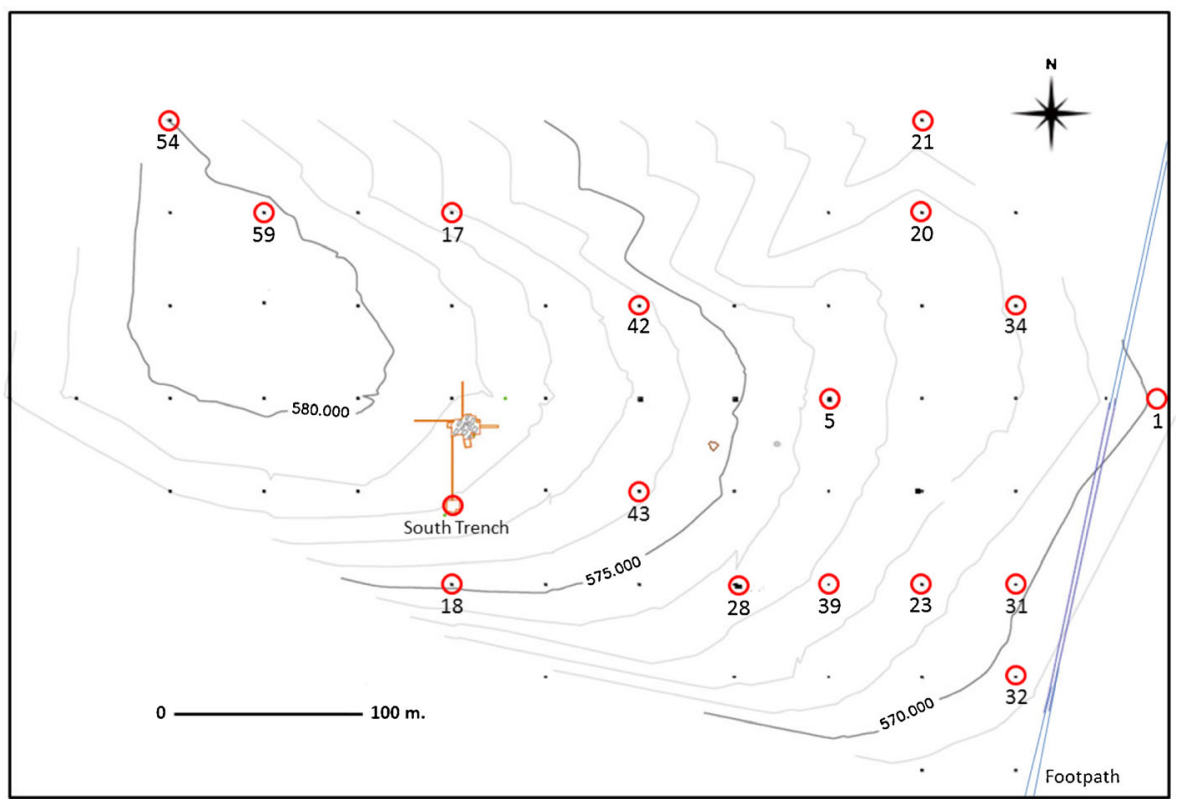

Fig. 9 Kindoki Hill: distribution of European potsherds. The numbers of the units where the material was found are indicated (image in full colour online)

mixed origin, the pit's content is homogeneous excluding possible contamination. After calibration, the radiocarbon-dated event is situated in the fourteenth century, thus prior to any European contact. No European material was discovered in the pit. Its

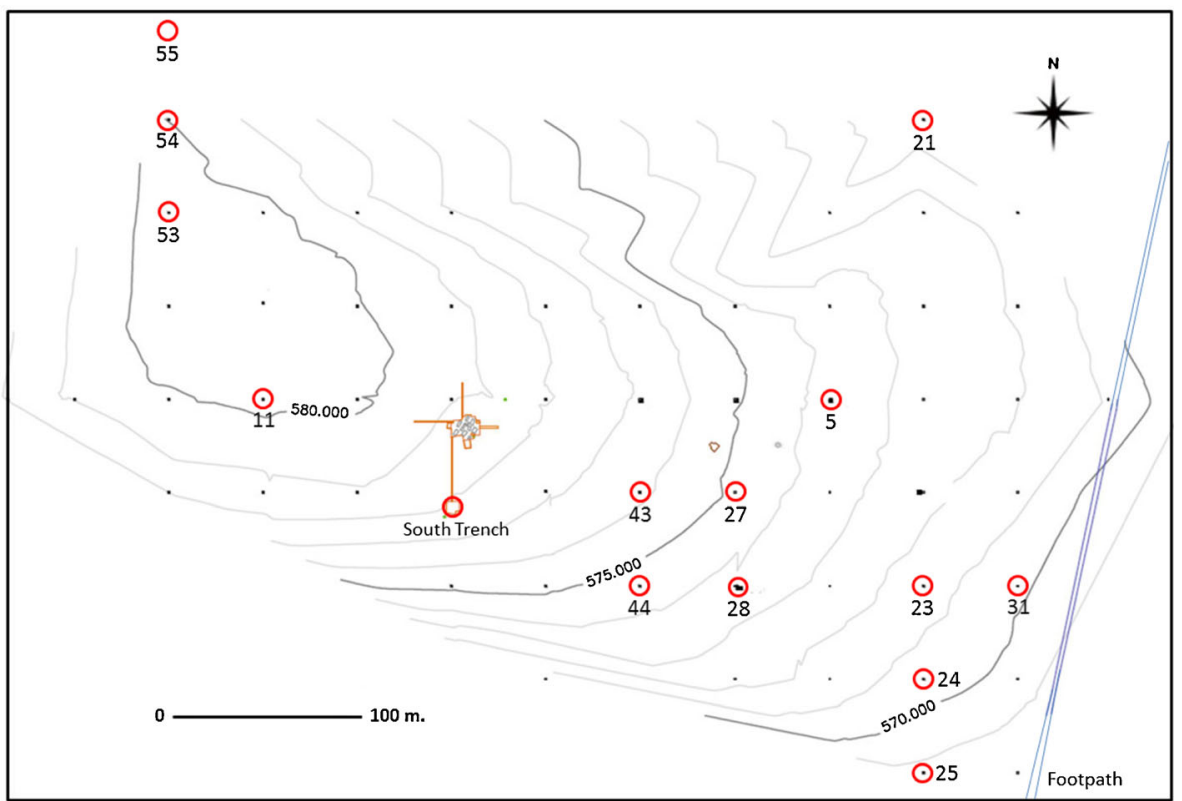

Fig. 10 Kindoki Hill: distribution of iron slag. The numbers of the units where the material was found are indicated (image in full colour online) 


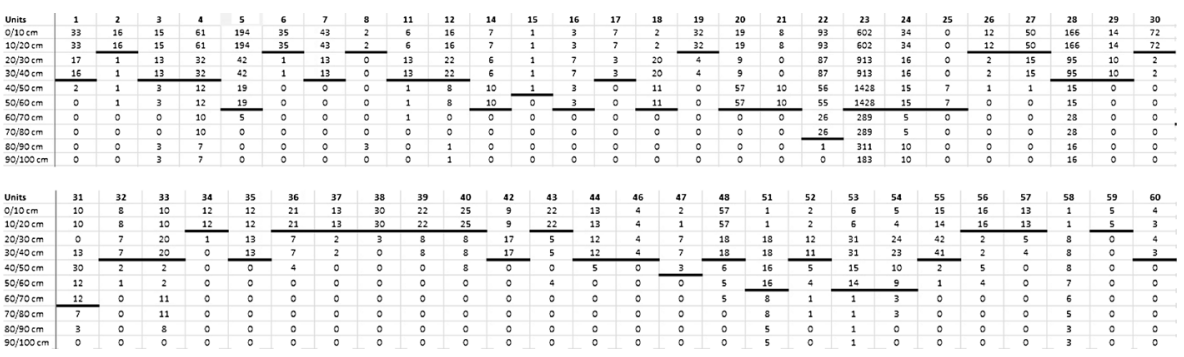

Fig. 11 Depth of artifacts scattered throughout the 60 excavated units at Kindoki showing a certain uniformity of their vertical dispersal on the 30-ha hilltop. The black bars indicate the vertical extent of the artifacts found

archaeological assemblage consists of one iron artifact and mainly pottery with a distinctive comb-impressed decoration. The cooking pots have everted lips and their shoulders are decorated with a band of comb impressions, which is delineated by horizontal incisions on the upper part of the shoulder. This decoration sometimes also appears on shallow bowls with the same clay fabric found in unit 28 . This pottery style was previously unknown from the Lower Congo region.

The same comb-impressed pottery was found in 17 other units and trenches at Kindoki (Fig. 7). Four more ${ }^{14} \mathrm{C}$ dates associated with that pottery were obtained, one from pit 5 in unit 23 (Poz-59446), one from pit 7 in unit 23 (Beta-382528), one from pit 10 in the cemetery area (Beta-333282), and one from an archaeological layer uncovered in 2012, at $-0.6 \mathrm{~m}$ in the south trench (Beta333283). In unit 23, comb-impressed potsherds, stone and terracotta smoking pipes, and a single European pottery fragment were found. In pit 5, located within unit 23, comb-impressed potsherds were mixed with several potsherds of different and probably more recent origin. In pit 7 of the same unit, no evidence of foreign potsherds was found. The archaeological layer excavated in 2012 contained both comb-impressed material and several pottery fragments strongly resembling Ngongo Mbata's "Group A" pottery (Vandenhoute 1973, pp. 93-95), itself related to Mortelmans" "Group IV" (Mortelmans 1962, p. 415). A small pit in the south trench opened from the base of this archaeological layer contained a nice terracotta smoking pipe bowl and another distinctive kind of pottery never found in the Lower Congo before (Fig. 12a (3)), but no comb-impressed potsherds. This new ceramic style was also excavated from unit 58 (upper $0.5 \mathrm{~m}$ ), again without any comb-impressed potsherds. The pit in the south trench was radiocarbon dated (Beta-333284) to similar time intervals as pit 5 in unit 23 (Poz-59446) and the -0.6-m layer in the south trench (Beta-333283), i.e., sixteenth century-first half of the seventeenth century.

Poz-59632 was collected deep in a pit in unit 58 on the western side of the hill. The assemblage consisted of potsherds associated with two iron objects. The pottery, which is often severely eroded, consisted of cooking pots similar to the pots of the sixteenthseventeenth centuries found in Ngongo Mbata though with several distinctive details (Clist et al. 2015), and pots with strongly everted rims and necks whose internal surface is decorated with a wavy line motif also visible on the external surface of the shoulder. This last very characteristic type of pottery is highly similar to both Ngongo Mbata's "Group B" pottery (Vandenhoute 1973, pp. 95-97) and Mortelmans" "Group V" 
a 1
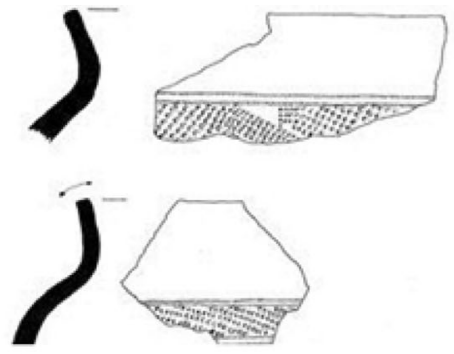

2
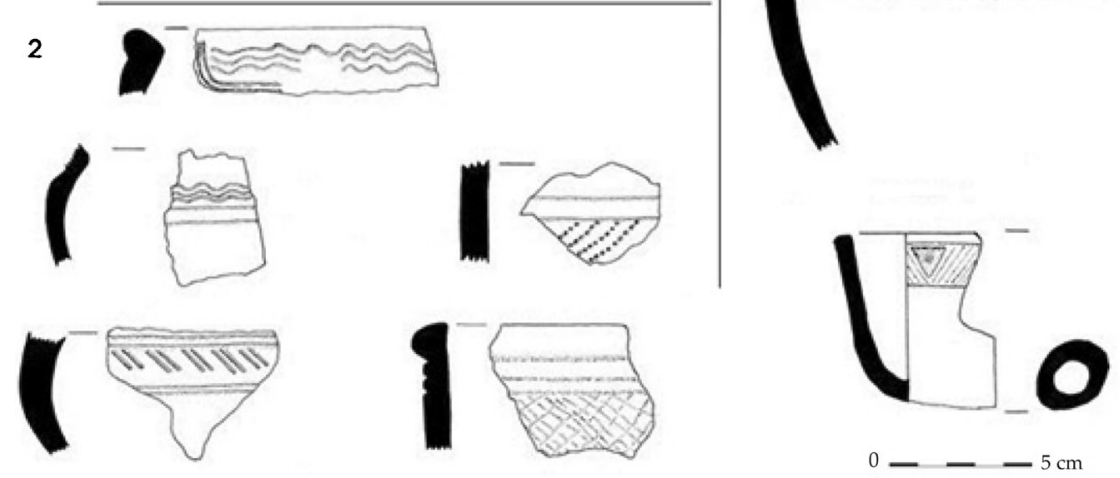

b
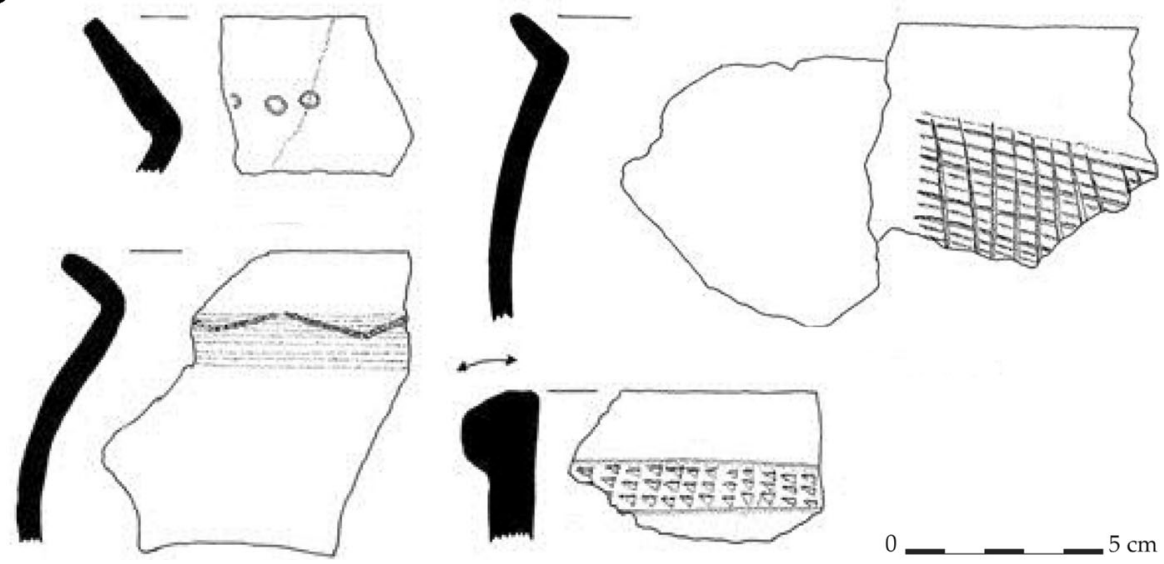

Fig. 12 a Kindoki Hill, south trench: 1 comb-impressed pottery; 2 artifacts from the lower layer at around $-60 \mathrm{~cm}$, containing Ngongo Mbata Group A pottery; and 3 pot and pipe bowl from a small pit. b Kindoki Hill, south trench: artifacts from the upper layer at around $-40 \mathrm{~cm}$

(Mortelmans 1962, pp. 415-416). It was also found in Kindoki unit 33 at the bottom of a small pit dated to the same calibrated time range of sixteenth century-first half of the seventeenth century (Poz-59445).

We thus have archaeological contexts where (1) comb-impressed pottery dated to the fourteenth century is the only type represented, (2) comb-impressed pottery is associated with other pottery types dated to the sixteenth-seventeenth centuries, and (3) no 


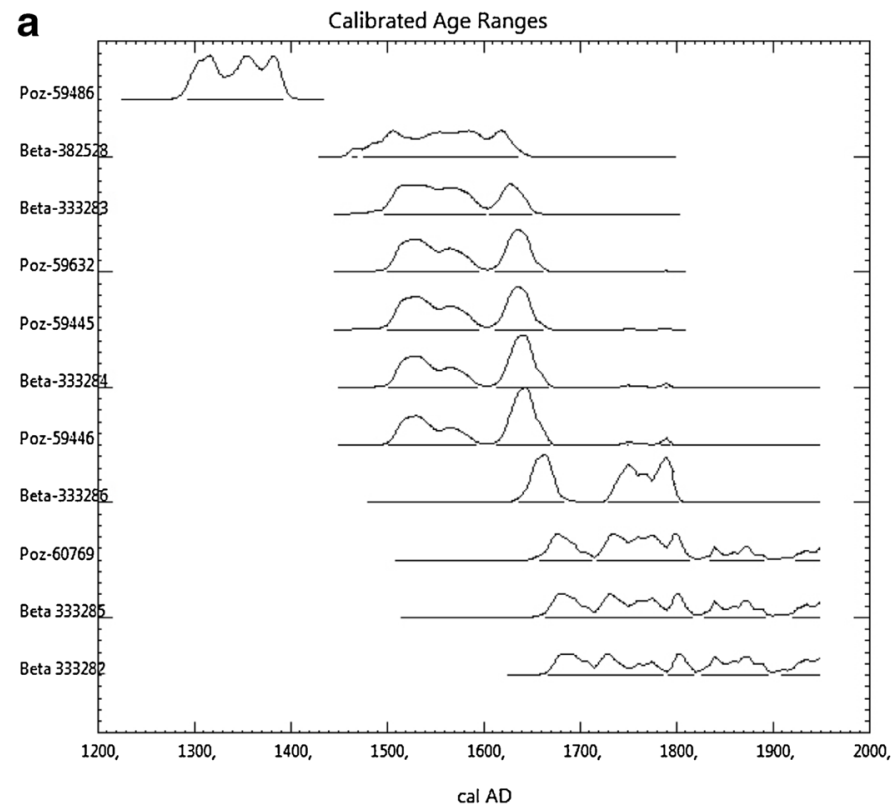

b

Kindoki, Mbanza Nsundi, DRC: radiocarbon dates \& dated artefacts

Calibrated Age Ranges

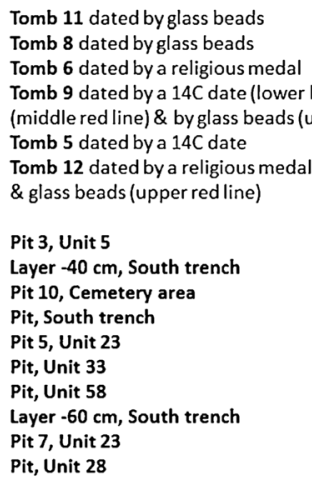

Pit 3, Unit 5

Layer $-40 \mathrm{~cm}$, South trench

Pit 10, Cemetery area

Pit, South trench

Pit 5, Unit 23

Pit, Unit 33

Pit, Unit 58

Layer $-60 \mathrm{~cm}$, South trench

Pit 7, Unit 23

Pit, Unit 28
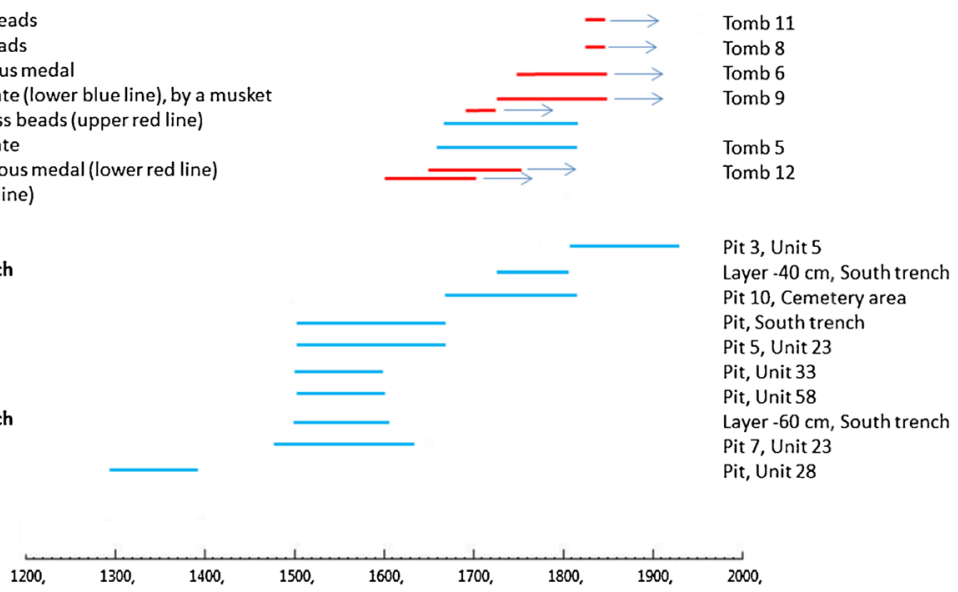

cal AD

Fig. 13 a Calibrated radiocarbon dates from Kindoki Hill. b Kindoki Hill: calibrated radiocarbon dates (lighter blue lines, at 2 sigma) and relative chronology of the cemetery tombs (darker red lines) (image in full colour online)

comb-impressed pottery occurs, but only other types of pottery dated to the sixteenthseventeenth centuries. Three possible hypotheses could account for these facts: (a) comb-impressed pottery dates back to a pre-European contact phase and all later 
Table 2 Radiocarbon dates from Kindoki Hill

\begin{tabular}{|c|c|c|c|}
\hline Location & Lab number & ${ }^{14} \mathrm{C}$ date $\mathrm{BP}$ & Calibrated date $\mathrm{AD}$ (at 2 sigma) and probabilities \\
\hline Pit 10 , cemetery area & Beta-333282 & $180 \pm 30$ & $\begin{array}{c}1668-1787(49 \%), 1792-1818(10 \%), 1827- \\
1894(27 \%) \text {, and } 1916-1949(14 \%)\end{array}$ \\
\hline Layer, south trench, $-0.6 \mathrm{~m}$ & Beta-333283 & $340 \pm 30$ & $1497-1602(74 \%)$ and 1606-1649 (26\%) \\
\hline Pit, south trench & Beta-333284 & $310 \pm 30$ & $1502-1593(54 \%)$ and $1613-1667(46 \%)$ \\
\hline Tomb 9, cemetery & Beta-333285 & $190 \pm 30$ & $\begin{array}{l}1665-1816(71 \%), 1830-1892(20 \%), \text { and } \\
1922-1949(9 \%)\end{array}$ \\
\hline Layer, south trench, $-0.4 \mathrm{~m}$ & Beta-333286 & $250 \pm 30$ & $1637-1683(38 \%)$ and $1729-1803(62 \%)$ \\
\hline Pit 7 , unit 23 & Beta-382528 & $370 \pm 30$ & $1476-1635(99 \%)$ \\
\hline Pit, unit $33,-0.7 /-0.8 \mathrm{~m}$ & Poz-59445 & $320 \pm 30$ & $1501-1595(63 \%)$ and $1612-1661(37 \%)$ \\
\hline Pit 5 , unit $23,-0.8 /-1 \mathrm{~m}$ & Poz-59446 & $305 \pm 30$ & $1502-1593(48 \%)$ and $1614-1669(51 \%)$ \\
\hline Pit 3 , unit $5,-0.5 /-0.6 \mathrm{~m}$ & Poz-59447 & $90 \pm 30$ & $1807-1929$ \\
\hline Pit, unit $28,-1.1 /-1.2 \mathrm{~m}$ & Poz-59486 & $680 \pm 30$ & $1294-1393(100 \%)$ \\
\hline Pit, unit $58,-1.8 /-1.9 \mathrm{~m}$ & Poz-59632 & $320 \pm 30$ & $1501-1595(63 \%)$ and $1612-1661(37 \%)$ \\
\hline Tomb 5, cemetery & Poz-60769 & $200 \pm 30$ & $\begin{array}{l}1658-1712(25 \%), 1718-1814(56 \%), 1835- \\
1891(13 \%) \text {, and } 1924-1949(6 \%)\end{array}$ \\
\hline
\end{tabular}

All ${ }^{14} \mathrm{C}$ dates were checked on October 3, 2014, using the Calib 7.0.2 program (latest version available online at http://calib.qub.ac.uk/calib/download/), using the Southern Hemisphere 2013 International calibration datasets

occurrences are from disturbed contexts, (b) comb-impressed pottery was used at Kindoki from the fourteenth to the sixteenth centuries before being superseded by the production unearthed from contexts of the sixteenth-eighteenth centuries, or (c) the fourteenth-century date is anomalous and the production period for comb-impressed pottery was limited to the sixteenth-seventeenth centuries.

The occupation phase attributed to the sixteenth-seventeenth centuries is buried at a depth of about 0.4 to $0.6 \mathrm{~m}$ and further encountered in several pits. It is represented by six ${ }^{14} \mathrm{C}$ dates obtained for Kindoki, i.e., Beta-333283, Beta-333284, Beta-382528, Poz59445, Poz-59446, and Poz-59632. Several of the pottery types linked with that habitation period also occur outside Kindoki, at Ngongo Mbata among others, where they were roughly dated to the same time range. Of the six ${ }^{14} \mathrm{C}$ dates for this habitation period, three are not associated with comb-impressed potsherds, two are but the sherds are mixed with other types, while just one date refers to an exclusive collection of comb-impressed potsherds (pit 7, unit 23).

A subsequent major domestic episode dated to the late seventeenth and eighteenth centuries is represented by a different pottery type found in the units' upper $0.4 \mathrm{~m}$ (Fig. 12b). Only two ${ }^{14} \mathrm{C}$ dates could be obtained for that period: Beta-333282 collected in the upper part of pit 10 immediately west of the cemetery ( $c f$. infra) and Beta-333286 from the upper archaeological layer of the south trench excavated in 2012. Pit 10 was dug from an ancient village occupation level at $0.4 \mathrm{~m}$. The village floor contained upper and lower grindstones in position, a charcoal layer of several square meters, and very few potsherds. The pit's filling was poor in content, but comprised several small combimpressed potsherds. The pottery with stone and terracotta smoking pipes of the dated upper layer (seventeenth-eighteenth centuries) is found around the hilltop in various units (Fig. 12b). 
Pit 10 clearly shows how individual comb-impressed potsherds can be found in the upper part of the soil, brought up from their original position at around $0.6 \mathrm{~m}$ or from a pit containing this pottery type. In unit 23 , we studied five pits, four of which were opened up below the humic layer. While pit 4 contained only more recent material and no comb-impressed potsherds, pits 5 and 6 had a preponderance of comb-impressed potsherds with a small series of typologically distinct pottery fragments. Pits 7 and 8 contained only comb-impressed potsherds. Recall that comb-impressed pottery was deposited elsewhere at around 0.4-0.6 m. Pits with comb-impressed material had to be dug out from this depth. Other evidence from unit 23 immediately around pit 7 shows a strong admixture with typologically distinct potsherds above $0.6 \mathrm{~m}$. Also, pit 4 shows more recent features dug into and through the preexisting comb-impressed level. The spatial and chronological proximity of pit 5 (Poz-59446) and pit 7 (Beta-382528) leads us to think that both relate to a more recent episode than the comb-impressed material. The only other more recent comb-impressed associated date is the one from the $-0.6-\mathrm{m}$ layer in the south trench (Beta-333283) which also contained mixed ceramic material. The $680 \mathrm{BP}$ date from the pit in unit 28 (Poz-59486) is the only one unmistakably associated with comb-impressed production and without any possible perturbation. This is why we argue that the comb-impressed pottery represents a fourteenth-century occupation period of the hill. The more recent dates associated with potsherds of this type are the result of perturbation of this archaeological layer by the settlement phase of the sixteenth-seventeenth centuries. This hypothesis is further strengthened if one considers the 1500-1670 calibrated dates with no trace of comb-impressed potsherds (Beta-333284 and Poz-59445) and ceramics typologically very similar to the finds at Ngongo Mbata dated to the seventeentheighteenth centuries (Clist et al. 2015). It is moreover noteworthy that the combimpressed pottery in unit 28 was found neither in association with ceramics of European produce nor with smoking pipes whose remains are dispersed in small quantities all over the hilltop. Even if smoking pipes were of local production, the practice of pipe smoking only developed after Europeans introduced tobacco from the Americas (Philips 1983).

Apart from the "Group A" pottery from Ngongo Mbata, several other types of Kongo pottery with production centers away from Kindoki have been detected on the hilltop. Several potsherds of the "Sumbi Group" were detected in units 23, 27, 31, 44, and 53 (see Fig. 4 for the location of these units). The production center of this as yet undated pottery tradition was situated north of the Congo River, more than $160 \mathrm{~km}$ away (Clist 1982, pp. 92-93). Furthermore, several white clay potsherds were found in unit 58, some of which were decorated. Such white clay material has commonly been attributed to the "Group X" associated with the Tio Kingdom situated further north on both banks of the Congo River (Pinçon 1988, pp. 4-5; de Maret and Stainier 1999, p. 486).

\section{Kindoki Cemetery}

In order to locate the old symbolic and ceremonial center of Mbanza Nsundi, Kindoki Hill was systematically surveyed in 2012 for possible ducal tombs. 
This led to the identification of 11 graves, all constructed in the same way and all oriented northeast/southwest at a $220^{\circ}$ orientation. The excavated area in 2013 ultimately extended to $168 \mathrm{~m}^{2}$ (Fig. 14). The tombs probably form a unit given their structural identity, their proximity to each other and the absence in a radius of $40 \mathrm{~m}$ of other similar structures. We probably uncovered all units belonging to this funerary phase.

Two types of graves could be distinguished on the basis of their size and stone structures (Fig. 14): five large burials with carefully set-up pavements under their covering cairns (group 1: graves 1,2, 7, 8,9) and five smaller ones without carefully placed stone pavements (group 2: graves 4, 5, 6, 11, 13). Burial 12 stood out, since it did not have a covering pavement, only a covering cairn on top of the grave's rectangular stone demarcation.

Both types of tombs share certain characteristics: (a) a rectangular pit dug down to ca. $2 \mathrm{~m}$, (b) a rectangular surface demarcation of stones either lying flat or on their side, (c) a topping pavement with more (group 1) or less (group 2) well-dressed stones, and (d) a covering cairn of stones of various sizes and shapes on top of the rectangular structure (Fig. 15).

Tomb 9 differed from the basic plan by the existence of two additional stone pavements carefully set up between the corpse and the covering pavement with interspersed layers of packed earth, respectively, 0.4 and $0.6 \mathrm{~m}$ thick. The second pavement was encountered at $0.87 \mathrm{~m}$, the third at $1.23 \mathrm{~m}$, while the burial was found at $1.82 \mathrm{~m}$. The remains were those of an adult in good condition and resting on its back, head to the southwest, arms alongside the body in a fully extended position (Fig. 16).

Table 3 provides a detailed inventory of each tomb. The skeletal remains and funerary deposits allowed the identification of six male and two female tombs. The sex of the individuals in the three remaining tombs remains unidentified.

Physical anthropological analysis of the skeletal remains contributes to a better comprehension of the cemetery's social structure and age/sex distribution. The male tombs are situated in the center (tombs 4-7, 9, and 12), while two female tombs are located to their east (tombs 8 and 11). Tombs 1, 2, and 13 situated west of the male tombs could not be sex-determined and also did not contain any sex-defining grave goods. They could either be male tombs, which would mean that the cemetery was organized according to a west/east division between men and women, or female tombs, which would imply that men were buried in the center and women on either side (Fig. 14). In the male group of tombs, tombs 6 and 12 contained children around 6 and 7 years old, while tomb 5 contained a 20-40-year old, and both tombs 7 and 9 a 40-60year old (Fig. 14). Tomb 9 also contained a burial of a $20-40$-year old whose skeleton was only partly preserved, maybe an earlier burial. The age of the individual in tomb 4 could not be determined. Both female tombs ( 8 and 11) contained 40-60-year olds. Tomb 8 also contained a second burial of a 20-40-year-old person. Both 40-60-yearold women, whose skeletons were among the better preserved, showed evidence of diffuse idiopathic skeletal hyperostosis, suggesting that the deceased had a metabolic disorder, like type II diabetes or obesity, and were overfed (Burner and Rosenthal 2009).

While tomb 9 contained the best-preserved skeletal remains, due to strong soil acidity all other tombs contained only partial skeletons - often legs and arms - or nothing at all (tomb 13). For eight graves, it looks as if the deceased were buried in exactly the same way: resting on their backs in a fully extended position with arms alongside the body- 


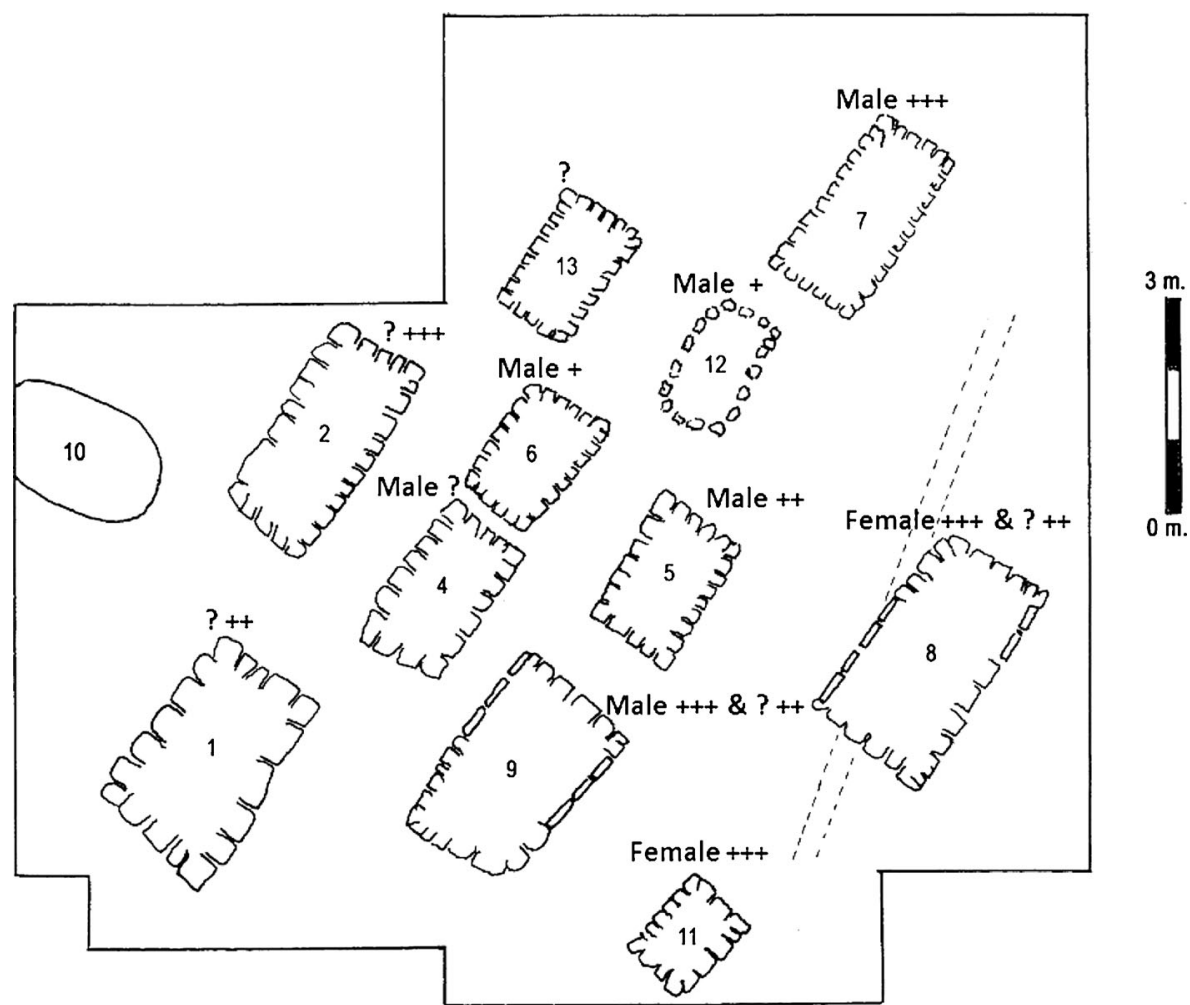

Fig. 14 Detail of the cemetery area on Kindoki Hill (with: + juveniles, ++ 20-40-year olds, +++ 40-60-year olds)

except in tomb 8 where the arms were folded on the abdomen - and heads directed to the southwest, the direction of Mbanza Kongo as seen from Kindoki. According to nineteenth-twentieth-century Kongo tradition, people were buried with the head to the west (i.e., toward Kongo di Ntete, the place of the origins) and the feet to the east (toward Kongo di Zole, the place of dispersal) (Mertens 1942, p. 348), which is further in line with Christian customs.

Data are too scanty to determine whether the deceased were buried in coffins, directly in the earth or wrapped in several layers of expensive carpets or blankets as was a customary practice among Kongo and other peoples of Central Africa (Van Wing 1921, pp. 280-281; Loir 1935, p. 58; Mertens 1942, pp. 339, 341; Thornton 1990, p. 13; Vansina 1994, p. 273). Nails around the likely position of the corpse, which would suggest the former presence of a wooden coffin, were only discovered in tomb 4 . The very dark earth surrounding the skeleton in tombs 1,8 , and 11 might suggest decomposed textile that was wrapped around the corpse. In want of any particular evidence, it could be that the other deceased were buried directly in the earth.

Five of the male tombs contained a sword. In two of them, no other funerary material was found (tombs 4 and 5). One had an additional religious medal (tomb 6), while another was rather rich in funerary objects (tomb 12). Tomb 9 is not only idiosyncratic in terms of architecture, but also in terms of material culture. It did not 


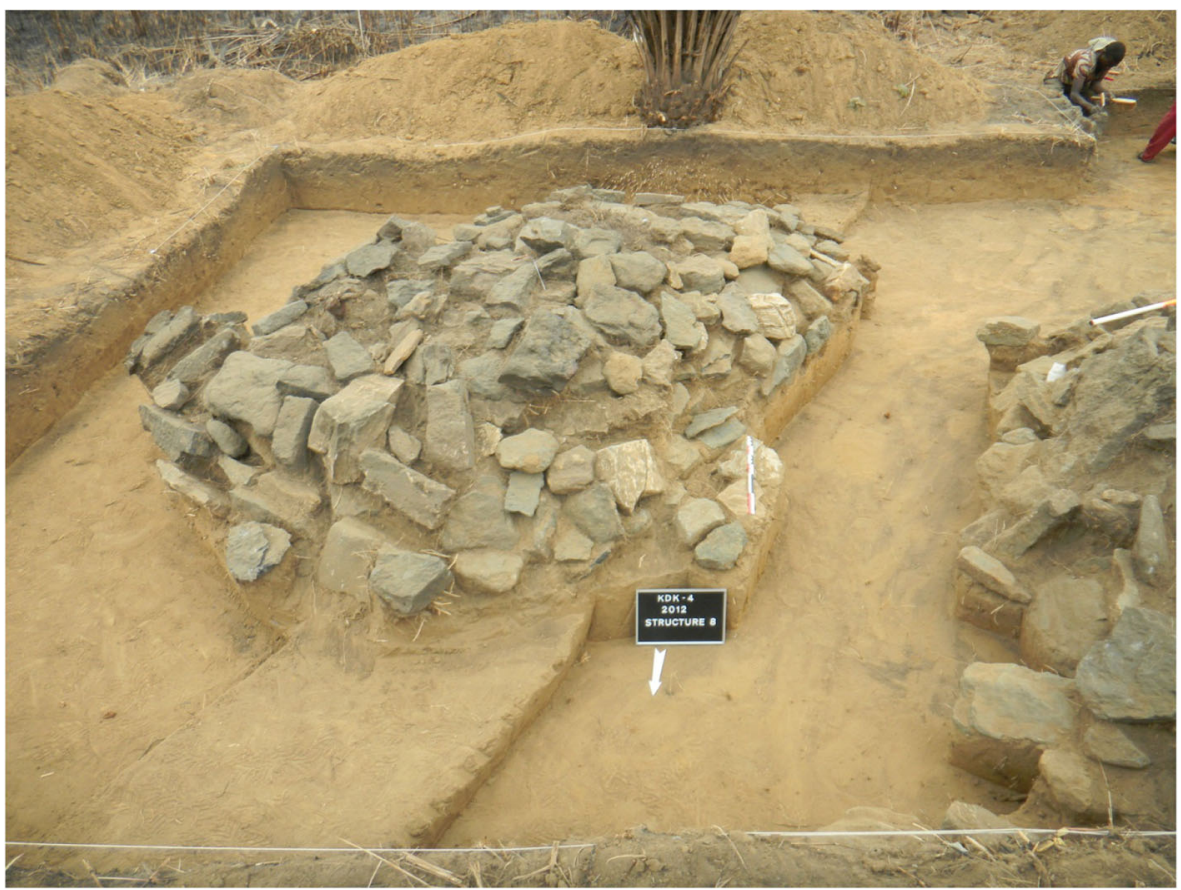

Fig. 15 Kindoki cemetery: stone structure of tomb 8 and the rubble stones which slipped to the living floor of the time (photo CKongoKing)

contain a sword, but a musket in association with two iron bracelets on the right arm and 18 Venetian glass beads relatively dated to $1725-1850$. Iron bracelets on the right arm were a marker of chieftaincy in Kongo tradition (Mertens 1942, p. 68). The cocked flintlock musket, possibly of the doglock style, still had the flint in position in the cock. According to P. Dubrunfaut (personal communication) of the Royal Museum of the Armed Forces and Military History in Brussels, the gun could be a "Boucanier," a type which was widely traded at the end of the seventeenth century. This find is truly unique: no other artifact of this type has been found during excavations in Central Africa, and Boucanier muskets in European collections are very rare (P. Dubrunfaut, personal communication). The musket was on the left of the body, like the swords in other male tombs, at a $45^{\circ}$ angle, its muzzle protruding through the first slab layer. Weeks (1914, p. 271) described a similar burial that took place in the late nineteenth century: "Makitu, a great chief of the Ngombe Lutete district, died and was buried in 1898. His coffin rested on three pieces of ivory cut from one tusk which he had saved for many years for this purpose. One loaded gun was buried with him, so that, when he arrived in the 'spirit forest,' he could shoot the witch (ndoki) who had caused his death."

Swords are a well-known Kongo symbol of power (Fromont 2011), and all are associated with the male tombs positioned in the center of the cemetery (Sengeløv 2014). The high social status associated with these swords must have been hereditary, since they were found in tombs 6 and 12 with the remains of male children aged, respectively, 7 and 6 . Such infant tombs had never been recorded before in the Lower Congo. The typology of the swords is diverse, except for the ones from tombs 7 and 12, 


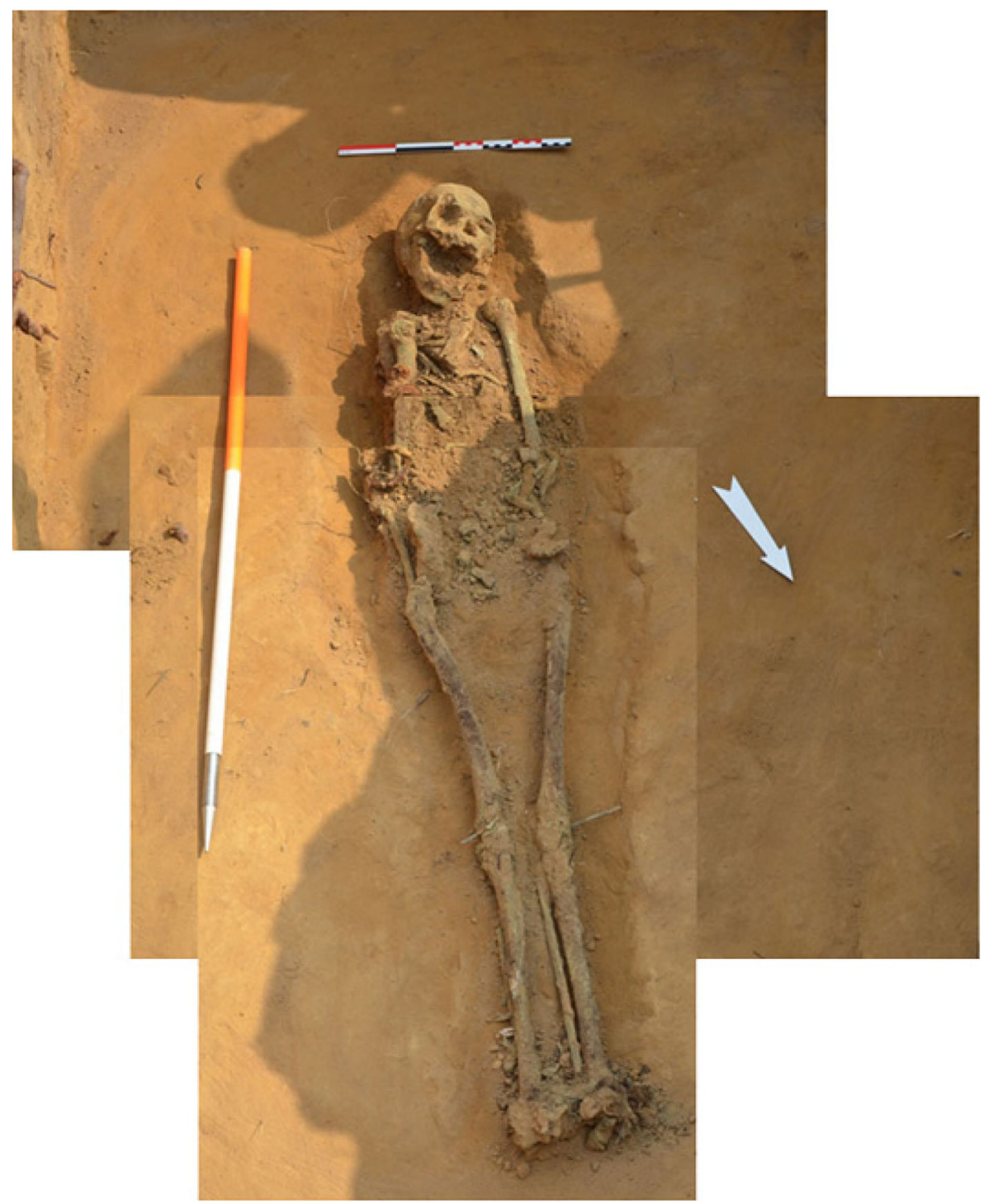

Fig. 16 Kindoki cemetery: male burial in tomb 9 (photo (CKongoKing)

which resemble each other (Fig. 17). On some swords, a piece of decoration on the hilt is well preserved, such as the putto-like head on the hilt of the sword from tomb 4 (Fig. 18). Like some other hilts, it is a piece of fine and high quality European ironwork that was reassembled with a locally produced blade of lesser quality (Sengeløv 2014). Two of the six male tombs also contained distinct Christian objects, such as religious medals (in tombs 6 and 12; Fig. 19), and a cross and a crucifix in copper (in tomb 12; Fig. 20).

The two female tombs are characterized by hundreds of beads of different types and by iron anklets not found in the male burials (Verhaeghe 2014). A single, simple iron anklet was found on the right foot of the woman in tomb 8, while the woman in tomb 11 wore six anklets, three on each ankle, with a single anklet weighing about half a 


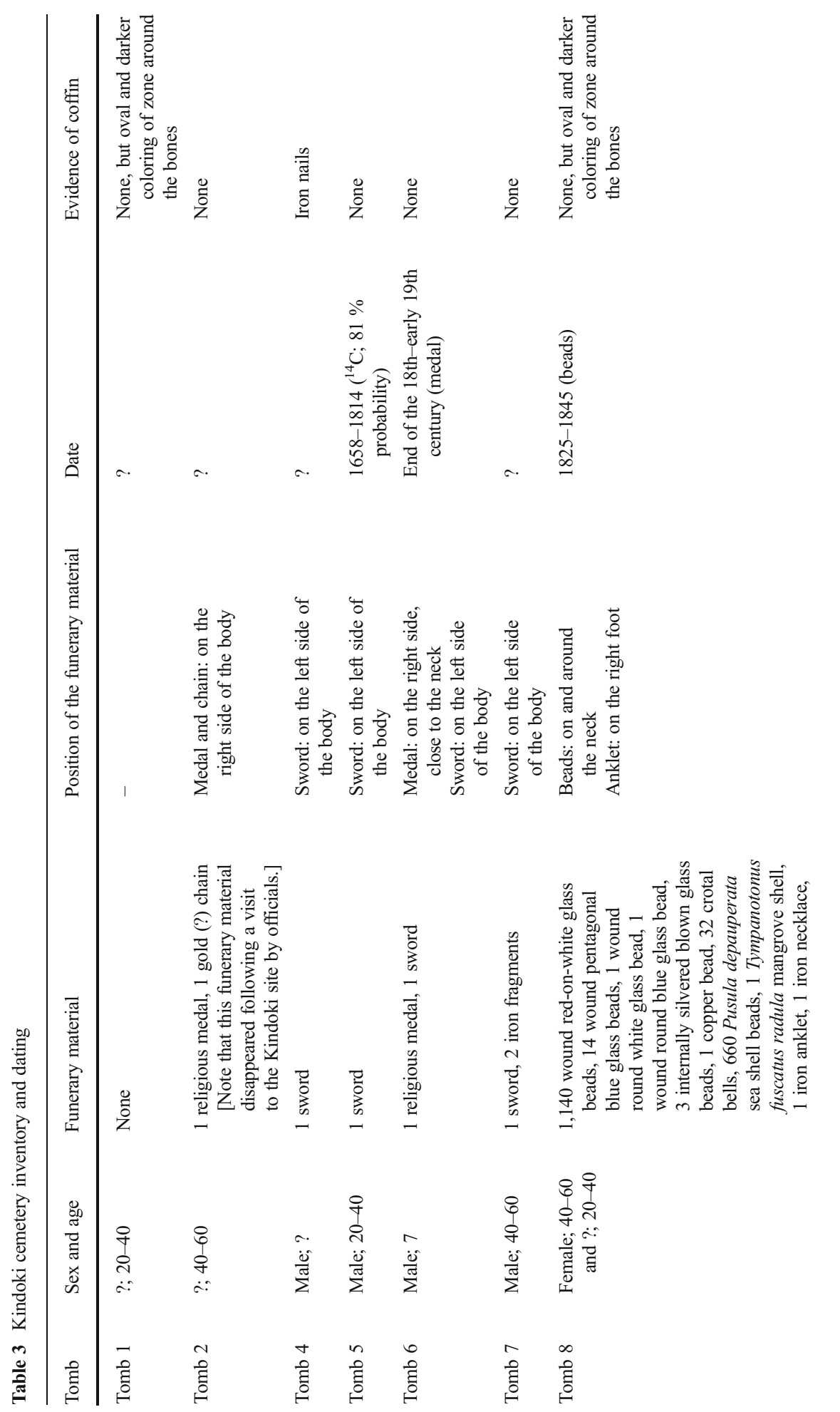




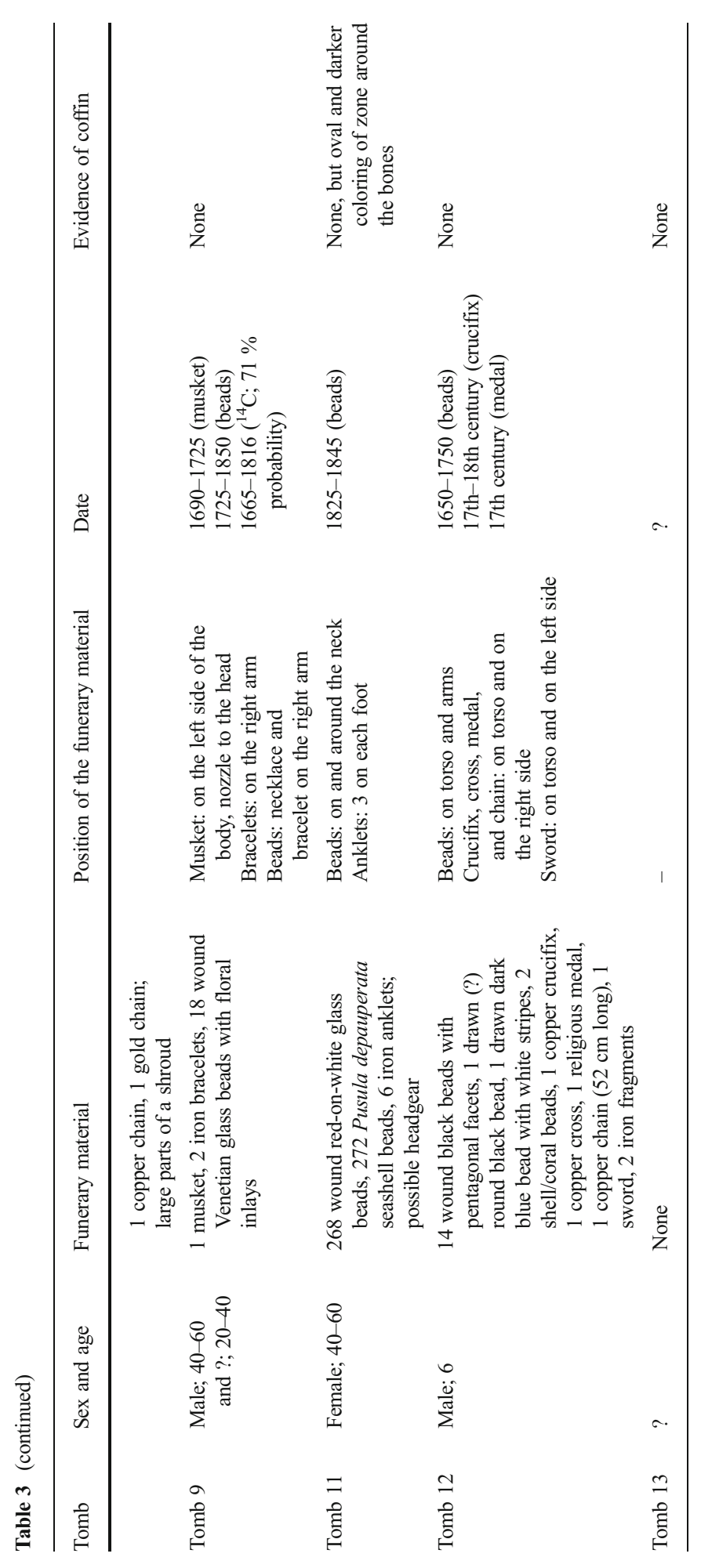



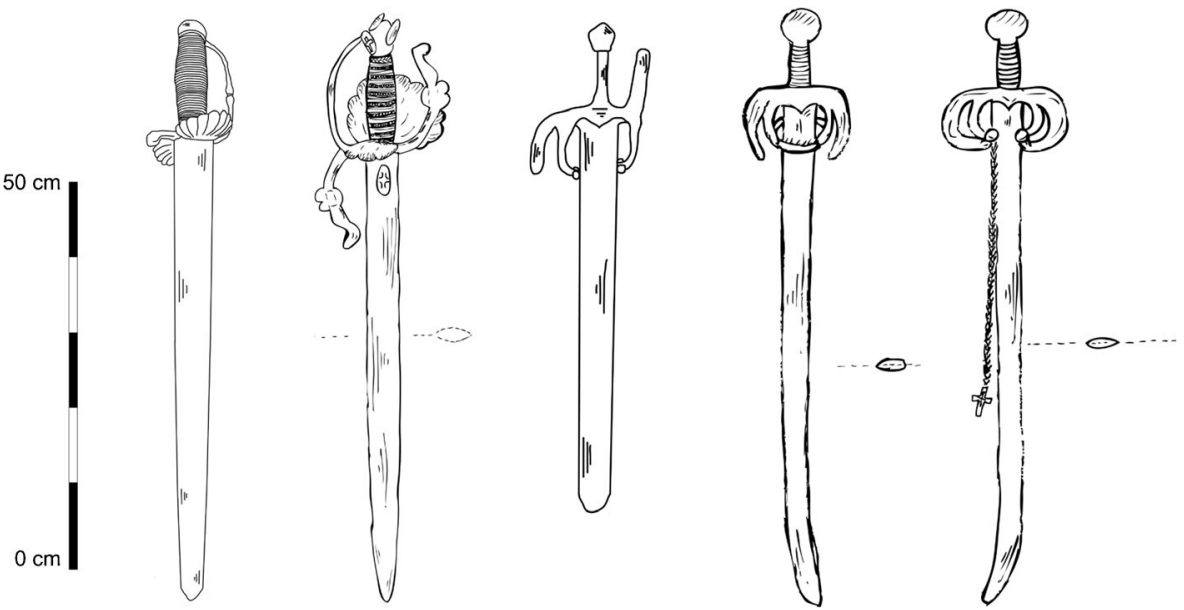

Fig. 17 Kindoki cemetery: swords from tombs 4, 5, 6, 7, and 12 (Sengeløv 2014, pp. 98-102)

kilogram. The two burials have the same red-on-white glass beads $(1,140$ beads in tomb 8 , 268 in tomb 11; see Fig. 21), and the same perforated Pusula depauperata seashells (660 in tomb 8, 272 in tomb 11; see Fig. 22). In addition, tomb 8 contained a much wider spectrum of bead types: copper, blown glass, and 14 characteristic pentagonal blue glass beads (Figs. 22 and 23). The fancy wound beads (with applied decoration) and the red-on-white are most likely of Venetian origin. Some of the smaller plain ones may also be Venetian, but it is quite likely that the larger pentagonal ones were produced in Bavaria and subsequently sold through Amsterdam. Tomb 8 also contained a gold chain broken into six segments (Fig. 24).

The three tombs to the west $(1,2,13)$ did not contain any high social status symbols and not a single bead. Two of the male tombs did contain beads, but in much smaller quantities: 18 in tomb 9 ( $c f$. above) and another 18 in tomb 12 (see Table 3). Interestingly enough, the types represented — shell/coral beads and likely Bavarian glass beads - are different from
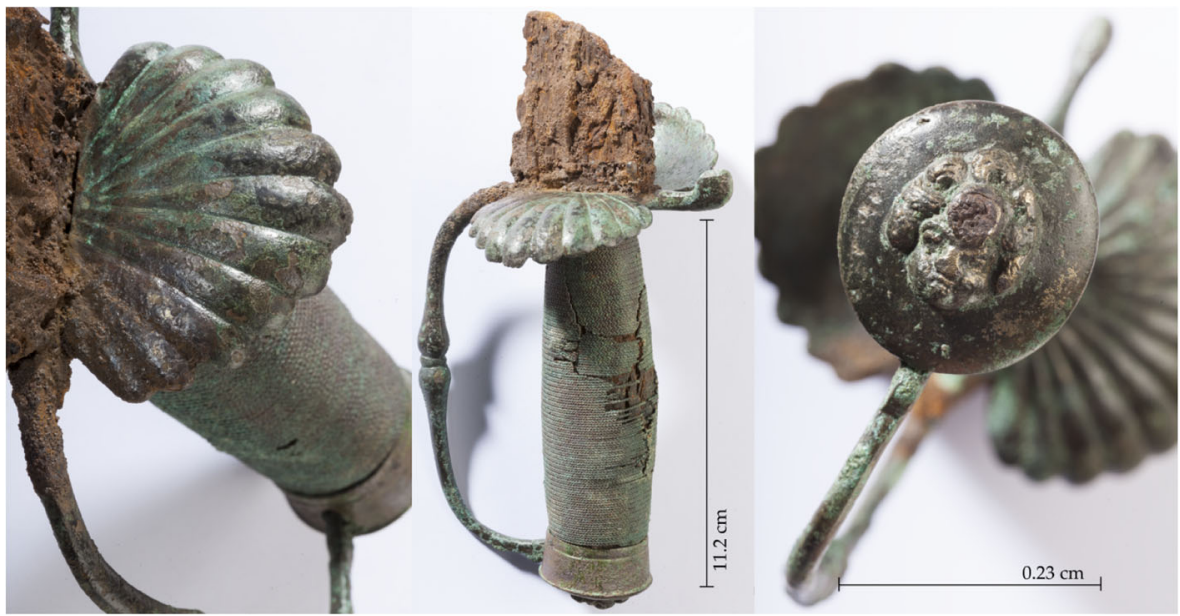

Fig. 18 Kindoki cemetery: hilt of the sword from tomb 4. Note the putto-like head on the top of the hilt (photo CKongoKing) 

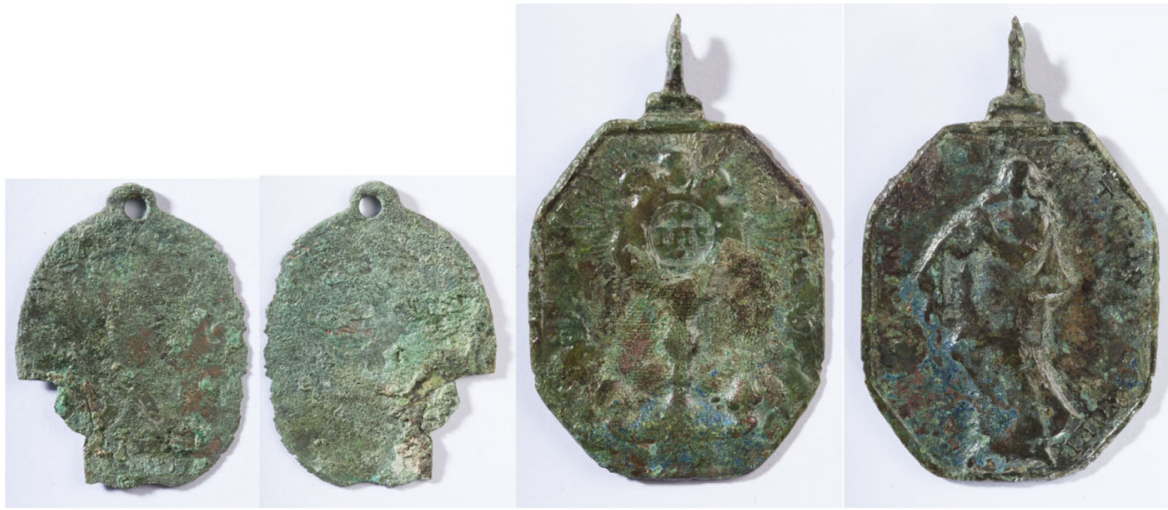

0

1

2

$3 \mathrm{~cm}$

Fig. 19 Kindoki cemetery: religious medals from tombs 6 (left) and 12 (right) (photo $\mathrm{CKongoKing)}$

the female-related beads. The glass bead types are also varied: facetted black, round black, round dark blue with white stripes, drop-shaped with wreath, white round, and little pink (Verhaeghe 2014).

The covering cairns on each grave further indicated that they date to roughly the same period. Some stones had slipped away from the covering cairn of each tomb and stabilized at the level of the old walking surface, slightly above pit 10 and its associated domestic layer dated to 1668-1818 (see Table 2). With most relative dates presented in Table 3 being

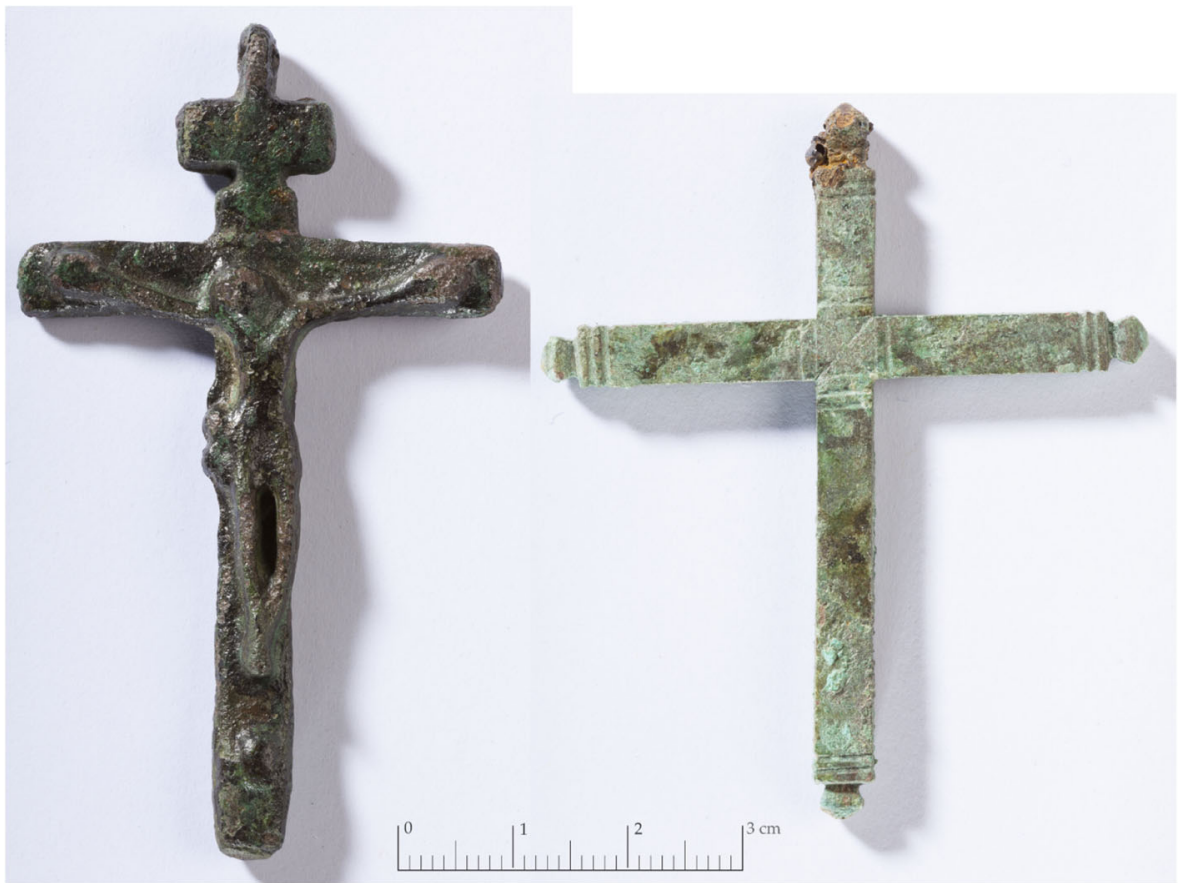

Fig. 20 Kindoki cemetery: copper crucifix and copper cross from tomb 12 (photo CKongoKing) 


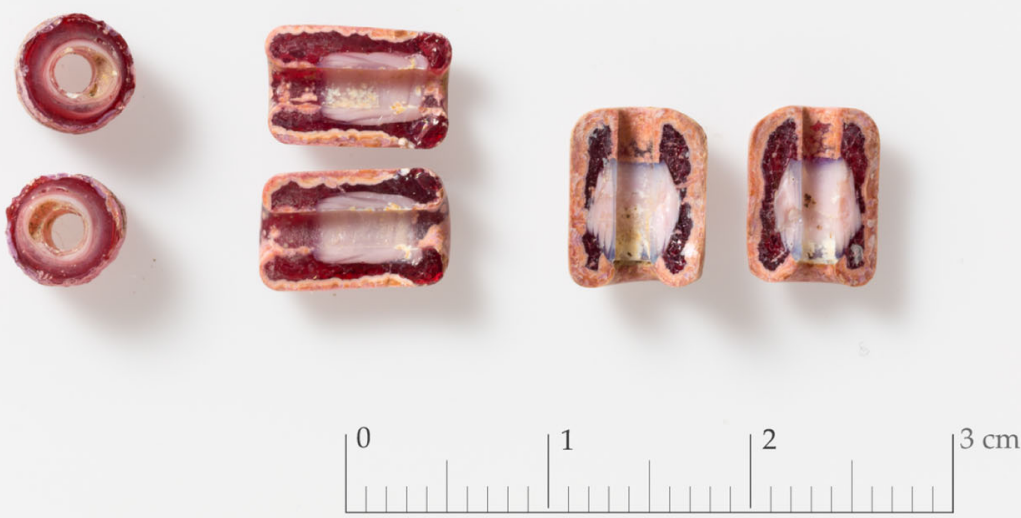

Fig. 21 Kindoki cemetery: cross section of wound red-on-white glass beads from tomb 8 (photo (CKongoKing) (image in full colour online)

more recent, this period can be considered as a terminus post quem for the whole cemetery. This level is now buried under some $0.3 \mathrm{~m}$ of sand (Fig. 15).

A 0.55 -m-wide earth feature that was compact and difficult to dig, its surface a thin layer of rocky plates each a few square centimeters in size, was found in 2012 to the south of tomb 8 . This feature continued under the tomb for several meters and could be traced back

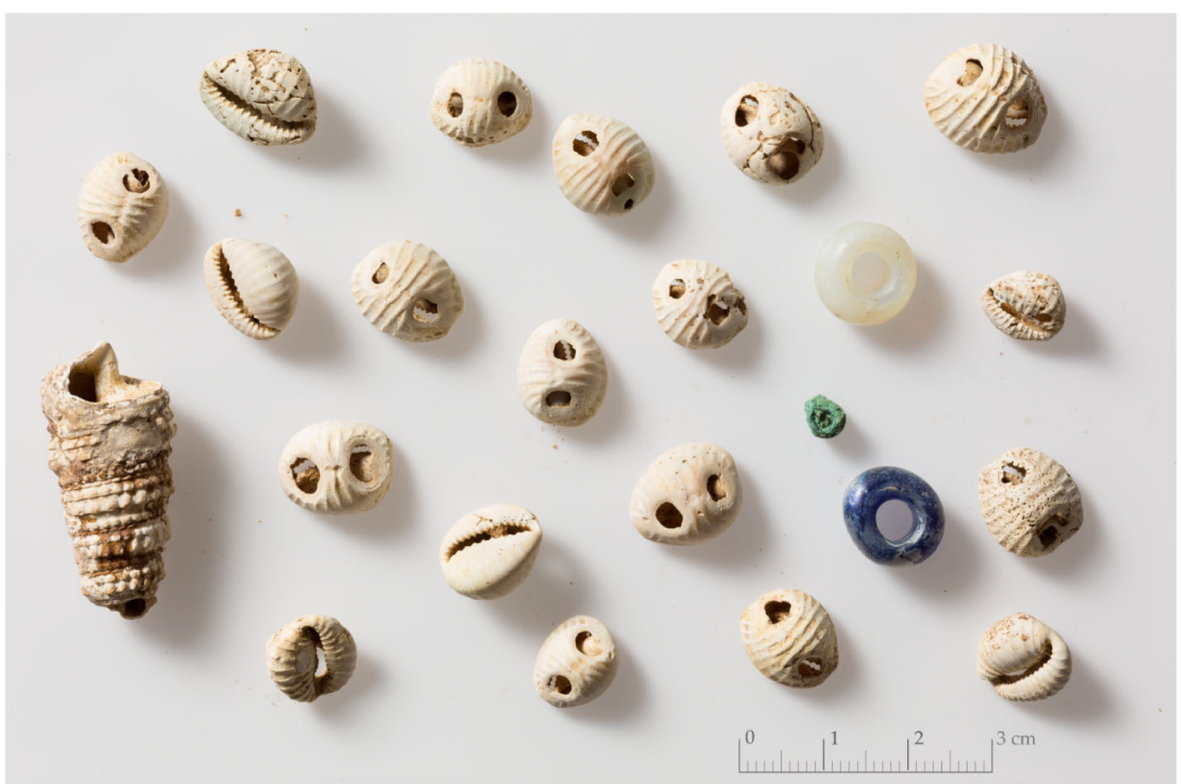

Fig. 22 Kindoki cemetery: a Tympanotonus fuscatus radula mangrove shell, Pusula depauperata sea shells, a wound round white glass bead, a wound round blue glass bead, and a copper bead, all from tomb 8 (photo CKongoKing) (image in full colour online) 


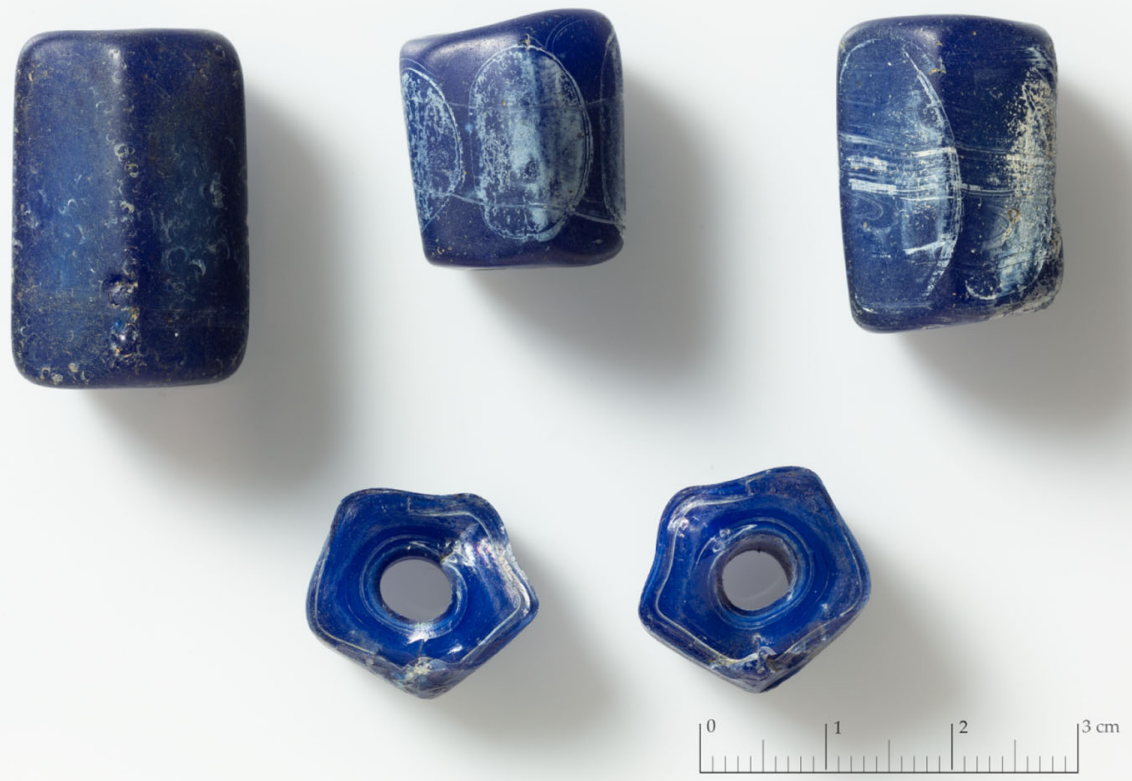

Fig. 23 Kindoki cemetery: wound pentagonal blue glass beads from tomb 8 (photo CKongoKing) (image in full colour online)

to the north of it (Fig. 14). It is presently interpreted as the base of an earth wall that predates the cemetery, perhaps linked to the nearby domestic area. Grinding stones were also found embedded in the covering stone cairn of tombs 5 and 9. It is possible that these grinding

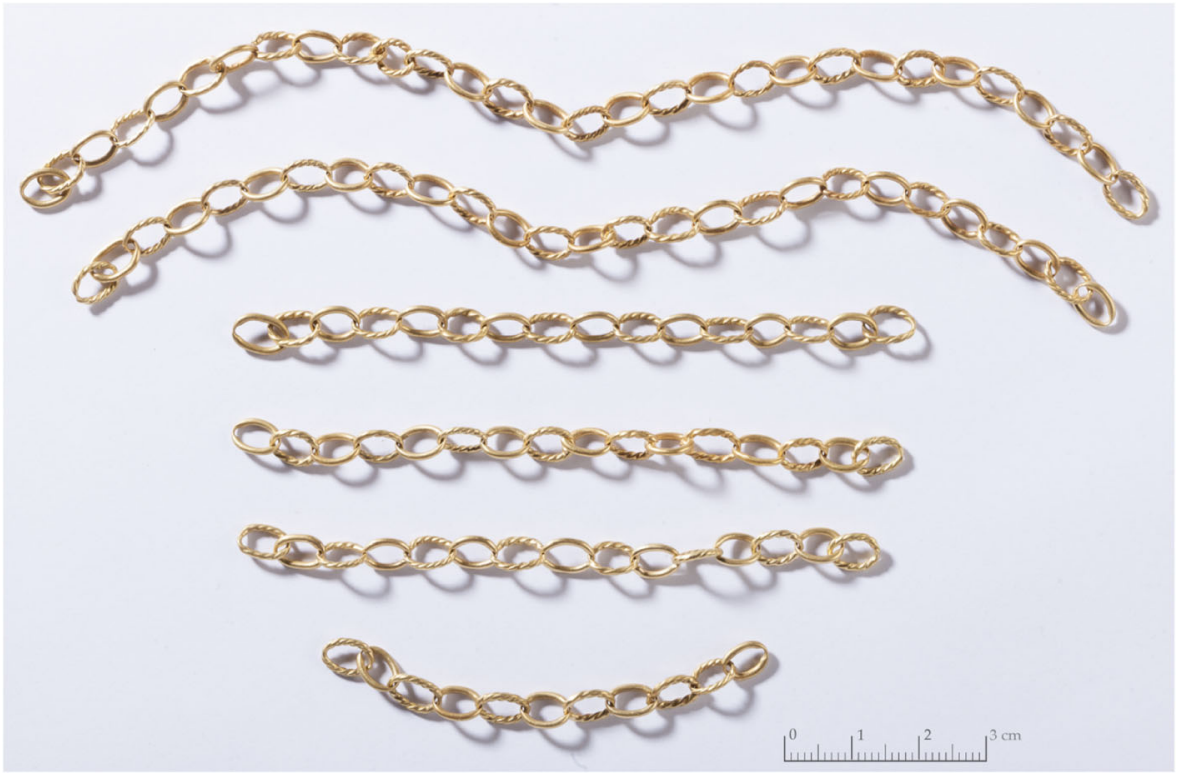

Fig. 24 Kindoki cemetery: gold chain from tomb 8 (photo CKongoKing) 
stones were picked up from the surface of the nearby village ruins, as they may have been sticking out of the sand layer there when the cemetery was established.

Finally, it is important to stress that the graves are limited in number, and several of the datable ones, either relatively or through radiocarbon dating, seem to succeed each other in time. Only six of the 11 tombs can be dated, though in a broad span of time. The data summed up in Table 3 show that tombs 5 and 12 are seventeenth-late eighteenth century at the latest. Tomb 9 was constructed after 1725 . Female tombs 8 and 11 could not have been dug before 1825 . Tomb 6 is situated between the oldest and most recent tombs, i.e., the end of the eighteenth-early nineteenth century. To make sense of this, and taking into consideration the spatial analysis of the tombs, we argue that the male tombs with swords are the oldest, positioned after AD 1668 (pit 10 near the cemetery) and probably throughout the eighteenth century, followed by male tomb 9 with the musket and the two female tombs during the first half of the nineteenth century.

\section{Discussion}

Nowhere else in Central Africa, except at Ngongo Mbata (Clist et al. 2013b, 2015), has a hilltop been excavated as extensively as at Kindoki. A total surface of about $398 \mathrm{~m}^{2}$ was archaeologically explored in 2012-2013. The archaeological material discovered at the site consists predominantly of Kongo material culture interspersed with some objects of European origin, in both cases mainly pottery. Densities, radiocarbon dates, and relative chronology related to these diverse artifacts indicate that the excavated part of Kindoki hosted a domestic area, which had its most dense occupation during the sixteenth and seventeenth centuries, but which villagers probably first inhabited during the fourteenth century. Human settlement continued until the start of Belgian colonization in the late nineteenth and early twentieth centuries. The hilltop also hosts a cemetery, which postdates the hilltop's principal habitation phase and contains several graves of people with high social status.

The dating of the hilltop's occupation to the fourteenth century is of key importance, not only because no other village settlement of that era was ever excavated in the Lower Congo region, but also because it brings us back to the emergence period of the Kongo Kingdom before the arrival of the first Europeans. If Kindoki Hill was indeed part of the Mbanza Nsundi mentioned in historical sources of the sixteenth-seventeenth centuries, it means that a settlement had been developing there since at least the fourteenth century. This would allow us, for the first time, to spatially bridge Kongo history and "prehistory." Nevertheless, it should be admitted that the fourteenth-century dating of Kindoki's earliest domestic area is still based on a single ${ }^{14} \mathrm{C}$ date. That date is associated with a distinctive type of combimpressed pottery which was never before found in the Lower Congo region but which is found all over the Kindoki hilltop (Fig. 7), though in high concentrations only on the eastern part of the hill. We have argued that later dates associated with this discriminatory pottery are in all likelihood due to the intrusion of the sixteenth- to seventeenth-century settlement layer into the hilltop's earliest village occupation.

Human settlement on the Kindoki hilltop clearly became denser during the sixteenth and seventeenth centuries, and distinct but nearby clusters of habitation started to develop as evidenced by separate zones of high artifact density both east and west of the later cemetery. During that period, Kongo kings were at the zenith of their power and the kingdom reached 
its highest degree of political centralization (Thornton 2001). As discussed above, the Nsundi Province had an important part to play in that process and its capital is often referred to in chronicles of that time. As a consequence, it is tempting to take the sixteenth- to seventeenth-century assemblages uncovered at Kindoki as the archaeological signature of Mbanza Nsundi during its heyday. The two domestic concentration zones could be interpreted as the remains of a nobleman's compounds, which chroniclers portrayed as constituting small villages on their own scattered over the hill(s) (cf. supra). The fact that they do not comprise a particularly sumptuous material culture should not be problematic in that regard. It is well-known from eyewitness testimony that Kongo nobility in that period may have had a larger compound, more servants, more leisure time, and certain (perishable) luxury goods, such as clothing, but they had in general very few artifacts that distinguished them from the commoners they governed (Thornton 1983, p. 18). At the same time, the soberness of noblemen's daily material life makes it very hard to distinguish a larger compound within a mbanza from a common village, especially if, for the time being, the coverage of excavations remains overall limited in space. Given that size was one of the main distinctive features of a mbanza, which could be scattered over several hills, mapping its entire area would require a multiyear excavation program. Taking into account sixteenthto seventeenth-century sources situating Mbanza Nsundi slightly to the west of the Inkisi River, the excavated area may well have been one of its quarters, but it probably did not constitute its core. If that were the case, one would expect to have found traces of the church mentioned in several historical sources and the open meeting place that was generally adjacent to Kongo churches and chapels during those times (Thornton 1984, p. 165). Such a plaza associated with the remains of a stone church, another small stone building, and the stone foundations of a monumental wooden cross could be reconstructed from the archaeological finds at Ngongo Mbata (Clist et al. 2015). If we had succeeded in locating, for instance, the church and the lodging house which the Capuchin missionaries maintained in Mbanza Nsundi in the mid-seventeenth century (Piazza 1976, p. 233), we would no doubt have been close to the former capital's ceremonial and administrative center where the duke and his court lived. This said, our large-scale excavation strategy relying on a 50-m grid does not guarantee that all important settlement features were found. Moreover, if Mbanza Nsundi's church was not built of durable materials, as seems to have been the case, it may be particularly hard to locate its possible vestiges, if any remain.

An observation suggesting that the sixteenth-seventeenth-century domestic areas were part of a larger center of affluence is the fact that ceramic finds from that period become more diverse. These also comprise a variety of types of Kongo pottery, which have contemporary counterparts in other archaeological sites situated within the realm of the Kongo Kingdom, such as Ngongo Mbata further south in the Inkisi Valley. This indicates that the excavated habitation area was connected to a regional exchange network in which European imports also circulated, as evidenced by the discovery of ceramics of European production, mainly Portuguese redware. Their quantities are significantly lower, though, than at Ngongo Mbata, which is known to have been an important trading post frequented by European merchants (Clist et al. 2015). Although Mbanza Nsundi was also situated in the proximity of trade routes connecting the Pool with Mbanza Kongo and on to Mbanza Soyo or Luanda along the coast (Fig. 1), it probably attracted fewer pombeiros or trade-middlemen. According to historical sources, missionaries seem to have been the most common European visitors to Nsundi’s capital. 
Another key element suggesting that the sixteenth- to seventeenth-century habitation zones were indeed part of a larger Mbanza Nsundi settlement is the discovery of the cemetery. Kindoki's archaeological record clearly testifies to the development of a burial place that is initiated in the early eighteenth century - maybe slightly earlierand continues for about a century. To judge from the funerary artifacts, the cemetery seems to have been reserved for people of noble descent. Moreover, the graves are limited in number and succeed each other in time. This seriation of tombs suggests that they were exclusively destined for high-rank titleholders, such as the dukes of Nsundi themselves. The discovery of male children's graves containing Kongo symbols of power possibly denotes that the people buried there were indeed holders of a hereditary title. Hence, this may indeed be "the dukes' graveyard" still remembered in twentiethcentury oral tradition. The buried women could be wives of the buried men, but could equally well be women-chiefs, also known as ndona from the Portuguese term for "lady," who were important ritual brokers in Kongo's political system until the twentieth century (Van Wing 1921, 1938; Mertens 1942; MacGaffey 2002, pp. 220223). If Nsundi dukes were indeed buried there in the eighteenth and nineteenth centuries, their mbanza, which was definitely of minor importance compared to the sixteenth- to seventeenth-century settlement, must have been situated in the neighborhood. The hilltop's archaeological record does provide scattered evidence for human occupation from the eighteenth century until the early twentieth century, though in much lower densities than during the sixteenth and seventeenth centuries. If during the eighteenth and nineteenth centuries the Duke of Nsundi indeed had his capital on Kindoki's hilltop, where he was buried, its ceremonial center must also have been located in the vicinity during previous centuries, either on Kindoki Hill itself or on one of the neighboring hills. As described by Van Wing (1938, p. 39), the principal cemetery in Kongo settlements, as elsewhere in Central Africa, was often the place where the founding father used to live and where he was buried within his own compound. The remaining compound members then moved elsewhere, but returned to the founding father's tomb to bury other deceased. Such a new cemetery used to be called a mbanza as well, a fact well reflected in Kongo dictionaries (e.g., Laman 1936, p. 523). The noun mbanza derives from a common Bantu stem that originally referred to a place cleared to build a compound; in Kikongo, it became the term that specifically refers to the settlement where a chief resides, i.e., a capital (Grégoire 1976). In contrast, common villages are known by the noun mavata in Kikongo, derived from a verb referring to the working of the land.

\section{Conclusions}

During the rise of the Kongo Kingdom, mbanza were important catalysts of political centralization. Kongo kings residing in Mbanza Kongo relied on the nomination of close relatives to the governorship of important provinces, such as Nsundi, to strengthen their grip on the kingdom's provinces, which often were formerly independent polities. Provincial mbanza, such as Mbanza Nsundi, thus became seats of power representing the central administration and hosting the duke, his retinue, and their households. In the old western Bantu tradition of "big men" to whom beneficial supernatural powers were attributed, Kongo provincial dukes were affluent leaders attracting crowds of people 
(Vansina 1990, pp. 73ff). This not only had an important demographic impact on mbanza, described by chroniclers as large outstretched settlements often occupying several adjacent hills, but also a symbolic one. In the process of political centralization, mbanza became conceptually more and more opposed to mavata. These mavata were small settlements inhabited by villagers who perpetuated an agricultural economy based on an exogamous matrilineal kinship system and who still controlled the land outside the centers of economic and political power. In contrast, mbanza were controlled by "nonproducers" whose prosperity was founded on slave labor and trade who increasingly adhered to a system of patrilineal descent categories to concentrate the wealth and power into the hands of the male descendants of the king and his nobility (Thornton 1983, pp. 16-17; Hilton 1985, p. 90). Demographically speaking, provincial capitals were certainly areas of denser settlement than common villages in the wider vicinity. However, in terms of spatial organization, they did not fundamentally differ from "the pattern of village or household enclosures surrounded by cultivated land" (Hilton 1985, p. 45). The distinction between mbanza and mavata was first and foremost a political and social divide and thus symbolic in nature. For archaeologists, who study the debris of daily practice, the symbolic distinctiveness of a mbanza may therefore prove particularly elusive, as it turned out to be at the Kindoki site.

Written accounts from the sixteenth and seventeenth centuries concur in situating the capital of the Nsundi Province on the west banks of the Inkisi, while oral traditions from the late nineteenth and twentieth centuries had it that it was located more precisely on the Kindoki hilltop in the vicinity of a current-day village called Mbanza Nsundi. We targeted this hilltop using a historically informed survey method that specifically aimed at coping with the expected spatial elusiveness of a rural mbanza site. Our approach has been only partially successful so far. We have succeeded in connecting with twentieth-century oral tradition in that we did uncover a cemetery containing graves of nobles who were successively buried there from the early eighteenth century, or possibly slightly earlier, up to the early nineteenth century. It dates back to the period immediately after the collapse of the Kongo Kingdom when the former provinces were no longer part of a central administration, but remained landmarks of regional identity. Dukes of Nsundi continued to be recognized as community leaders and were upon their death in all likelihood buried in the graveyard we excavated on the Kindoki hilltop. The eighteenth- to nineteenth-century residential center of Mbanza Nsundi must have been situated in the immediate vicinity. No similar cemetery of Nsundi governors could be discovered for the period corresponding to the heyday of the Kongo Kingdom, i.e., the sixteenth-seventeenth centuries, let alone for the pre-European contact era. The Kindoki hilltop did host denser settlements during the sixteenth and seventeenth centuries and possibly a smaller settlement as early as the fourteenth century. Given the density of artifacts and the presence of European produce, it is rather unlikely that the sixteenth- to seventeenth-century settlements were simply contemporaneous with nearby villages or mavata. However, it is difficult to assess whether these were also part of Mbanza Nsundi's central unit or just peripheral quarters. The foreign, especially Portuguese, ceramics excavated on the hilltop and the hundreds of Venetian and likely Bavarian beads found in the graves are certainly indicative of Mbanza Nsundi's connection to trade routes linking the Atlantic coast with the Pool region.

Although our excavation methodology resulted in the identification of a larger Kongo settlement on the Kindoki hilltop, as a first in the archaeology of the Lower 
Congo, it also met its limits. In want of earlier nobility graves, as the ones uncovered in Mbanza Nsundi for a more recent period or of distinctive (stone) architecture as discovered in Ngongo Mbata, the archaeological signature of a rural mbanza site remains particularly challenging to decipher. More fine-grained controlled excavations on Kindoki Hill using open-area excavations and possibly electronic prospection, as well as an extension of our basic strategy-whereby systematic test excavations are combined with a large-scale grid approach — to hilltops surrounding Kindoki, are necessary to answer the outstanding questions.

Acknowledgments This research was funded by Starting Grant No. 284126 of the European Research Council and by the Special Research Fund of Ghent University. With regard to the fieldwork carried out for this article, our thanks go to the district and village chiefs of Mbanza Nsundi, Songololo, and Kindoki and the more than 50 paid workers from the neighborhood of Kindoki who excavated with us and helped us to maintain our base camp. The KongoKing excavation team (B. Clist, P. de Maret, E. Cranshof, M. Kaumba, and I. Matonda) was assisted by J. Yogolelo and A. Nkanza Lutayi (IMNC), N. Vanhaeren (Geography Department, Ghent University), as well as C. Verhaeghe and A. Sengeløv (Archaeology Department, Ghent University). N. Vanhaeren also undertook topographical measurements of the entire hilltop. We further wish to thank Prof. J. Sabakinu, the staff of the Procure Sainte Anne, and the team at the Institut des Musées Nationaux $d u$ Congo (IMNC), especially its director J. Imbongo and his staff at the archaeology section, who greatly facilitated administrative and practical issues in Kinshasa. Special thanks go to Dr. D. Fehse of the Zoological State Collection in Munich for the preliminary identification of the Pusula depauperata shells and Mr. P. Dubrunfaut of the Royal Museum of the Army and Military History in Brussels for his help in the identification and dating of the musket found in tomb 9. We gratefully acknowledge the input from Inge Brinkman, Pierre de Maret, and John Thornton, as well as the two anonymous peer reviewers selected by the Journal. Their thoughtful comments helped us to improve the original manuscript. The usual disclaimers obviously apply.

\section{References}

Abranches, H. (1991). Sobre os Basolongo: Arqueologia da tradição oral. Gent: Fina Petróleos de Angola.

Andah, B. W. (1995). Early urban societies and settlements of the Guinea and savannah regions of West Africa. West African Journal of Archaeology, 25(1), 103-152.

Axelson, S. (1970). Culture confrontation in the lower Congo: From the Old Congo Kingdom to the Congo Independent State with special reference to the Swedish missionaries in the 1880's and 1890's. Falköping: Gummessons.

Bairoch, P. (1988). Cities and economic development: From the dawn of history to the present. Chicago: The University of Chicago Press.

Bentley, H. M. (1907). W. Holman Bentley: The life and labours of a Congo pioneer. London: The Religious Tract Society.

Bequaert, M. (1940). Fouille d'un cimetière du XVIIe siècle au Congo Belge. L'Antiquité Classique, 9, 127-128.

Bontinck, F. (Ed.). (1964). Jean-François de Rome, O.F.M. Cap., La fondation de la mission des Capucins au Royaume du Congo (1648), traduit et annoté par François Bontinck. Louvain-Paris: Editions Nauwelaerts - Béatrice-Nauwelaerts.

Bontinck, F. (Ed.). (1970). Diaire congolais (1690-1701) de Fra Luca da Caltanisetta, traduit du manuscrit italien inédit et annoté par François Bontinck, C.I.C.M. Louvain-Paris: Editions Nauwelaerts - Béatrice-Nauwelaerts.

Bostoen, K., Ndonda Tshiyayi, O., \& de Schryver, G.-M. (2013). On the origin of the royal Kongo title ngangula. Africana Linguistica, 19, 53-83.

Bostoen, K., \& de Schryver, G.-M. (2015). Linguistic innovation, political centralization and economic integration in the Kongo kingdom: Reconstructing the spread of prefix reduction. Diachronica, 32(2), 139-185. 
Brásio, A. (Ed.). (1952). Monumenta missionária Africana. Vol. I, África ocidental (1471-1531). Lisboa: Agência Geral do Ultramar.

Brásio, A. (Ed.). (1954). Monumenta missionária Africana. Vol. IV, África ocidental (1469-1599). Lisboa: Agência Geral do Ultramar.

Burner, T. W., \& Rosenthal, A. K. (2009). Diabetes and rheumatic diseases. Current Opinion in Rheumatology, 21(1), 50-54.

Cahen, D. (1981). Contribution à la chronologie de l'âge du fer dans la région de Kinshasa (Zaïre). In C. Roubet, H.-J. Hugot, \& G. Souville (Eds.), Préhistoire africaine: Mélanges offerts au Doyen Lionel Balout (pp. 127-137). Paris: Editions A.D.P.F.

Casimiro, T. M. (2011). Portuguese faience in England and Ireland. Oxford: Archaeopress.

Chittick, N. H. (1974). Kilwa: An Islamic trading city on the East African coast. Nairobi: The British Institute in Eastern Africa.

Chittick, N. H. (1984). Manda. Excavations at an island port on the Kenyan coast. Nairobi: The British Institute in Eastern Africa.

Clist, B. (1982). Etude archéologique du matériel de la mission Maurits Bequaert de 1950-1952 au BasZaïre. Mémoire de Licence, Université libre de Bruxelles.

Clist, B. (1991). L'archéologie du royaume kongo. In R. Lanfranchi \& B. Clist (Eds.), Aux origines de l'Afrique centrale (pp. 253-256). Libreville: Centres Culturels Français d'Afrique Centrale, CICIBA.

Clist, B. (2012). Pour une archéologie du royaume Kongo: La tradition de Mbafu. Azania, 47(2), 175-209.

Clist, B., de Maret, P., de Schryver, G.-M., Kaumba, M., Matonda, I., Cranshof, E., \& Bostoen, K. (2013a). The KongoKing Project: 2012 fieldwork report from the Lower Congo Province (DRC). Nyame Akuma, $79,60-73$.

Clist, B., de Maret, P., Livingstone-Smith, A., Cranshof, E., Kaumba, M., Matonda, I., Mambu, C., Yogolelo, J., \& Bostoen, K. (2013b). The KongoKing Project: 2013 fieldwork report from the Lower Congo Province (DRC). Nyame Akuma, 80, 22-31.

Clist, B., Cranshof, E., de Schryver, G.-M., Herremans, D., Karklins, K., Matonda, I., Steyaert, F. \& Bostoen, K. (2015). African-European contacts in the Kongo Kingdom (sixteenth-eighteenth centuries): New archaeological insights from Ngongo Mbata (Lower Congo, DRC). International Journal of Historical Archaeology, 19(3), 464-501.

Connah, G. (1975). The archaeology of Benin: Excavations and other researches in and around Benin City, Nigeria. Oxford: Oxford University Press.

Connah, G. (2001). African civilizations. An Archaeological perspective. Cambridge: Cambridge University Press.

Connah, G. (2008). Urbanism and the archaeological visibility of African complex societies. Journal of African Archaeology, 6(2), 233-241.

Coquery-Vidrovitch, C. (2005). The history of African cities south of the Sahara: From the origins to colonization. Princeton: Markus Wiener Publishers.

Cuvelier, J. (1946). L'ancien royaume de Congo. Bruges: Desclée De Brouwer.

Cuvelier, J., \& Jadin, L. (1954). L'ancien Congo d'après les archives romaines (1518-1640). Bruxelles: Académie royale des sciences coloniales.

Da Silva Domingos, S. L. (2009). Les séries céramiques des amas coquilliers de la région de Luanda (Angola). Contribution à l'étude de la préhistoire récente angolaise. Thèse de doctorat, Université de Toulouse-Le Mirail, Toulouse.

de Bouveignes, O., \& Cuvelier, J. (1951). Jérôme de Montesarchio : Apôtre du vieux Congo. Namur: Grands Lacs.

De Kind, J., de Schryver, G.-M., \& Bostoen, K. (2012). Pushing back the origin of Bantu lexicography: The Vocabularium Congense of 1652, 1928, 2012. Lexikos, 22, 159-194.

de Maret, P. (1972). Etude d'une collection de céramiques protohistoriques du Bas-Zaïre. Mémoire de Licence, Université libre de Bruxelles.

de Maret, P. (1986). The Ngovo Group: An industry with polished stone tools and pottery in Lower-Zaïre. African Archaeological Review, 4(1), 103-133.

de Maret, P. (1990a). Le "néolithique" et l'âge du fer ancien dans le sud-ouest de l'Afrique centrale. In R. Lanfranchi \& D. Schwartz (Eds.), Paysages quaternaires de l'Afrique centrale atlantique (pp. 447-457). Paris: ORSTOM.

de Maret, P. (1990b). Phases and facies in the archaeology of Central Africa. In P. Robertshaw (Ed.), A history of African archaeology (pp. 109-134). London: James Currey; Heinemann.

de Maret, P. (2002). Urban origins in Central Africa: The case of Kongo. In P. Sinclair (Ed.), The development of urbanism in Africa from a global perspective (pp. 1-15). Uppsala: Uppsala Universitet, Institutionen 
för arkeologi och antik historia, Afrikansk och jämförande arkeologi. http://www.uu.se/digitalAssets/9/ 9594_DemaretAll.pdf.

de Maret, P. (2006). What to expect in excavating the Kongo Kingdom capital. In H.-P. Wotzka (Ed.), Grundlegungen. Beiträge zur europäischen und afrikanischen Archäologie für Manfred K.H. Eggert (pp. 319-328). Tübingen: Francke Attempto Verlag.

de Maret, P. (2013). Recent farming communities and states in the Congo Basin and its environs. In P. Mitchell \& P. Lane (Eds.), Oxford handbook of African archaeology (pp. 875-886). Oxford: Oxford University Press.

de Maret, P., \& Clist, B. (1985). Archaeological research in Zaïre. Nyame Akuma, 26, 41-42.

de Maret, P., \& Stainier, X. (1999). Excavations in the upper levels at Gombe and the early ceramic industries in the Kinshasa area (Zaïre). In G. Smolla, F.-R. Herrmann, I. Schmidt, \& F. Verse (Eds.), Festschrift für Günter Smolla (pp. 477-486). Wiesbaden: Selbstverlag des Landesamtes für Denkmalpflege Hessen.

de Munck, J. (1971). Kinkulu kia nsi eto a Kongo. Histoire de l'ancien royaume du Kongo. Matadi: Diocèse de Matadi.

Denbow, J. (1990). Congo to Kalahari: Data and hypotheses about the political economy of the western stream of the Early Iron Age. African Archaeological Review, 8(1), 139-176.

Denbow, J. (2012). Pride, prejudice, plunder, and preservation: Archaeology and the re-envisioning of ethnogenesis on the Loango coast of the Republic of Congo. Antiquity, 86(332), 383-408.

Denbow, J. (2014). The archaeology and ethnography of Central Africa. Cambridge: Cambridge University Press.

Dupont, E. (1887). Découverte faite par M. le capitaine commandant d'artillerie Zboïnski, d'instruments de l'âge de la pierre dans l'Etat du Congo. Bulletin de l'Académie royale de Belgique, 3e Série, 13, 407-409.

Dupré, M.-C., \& Pinçon, B. (1997). Métallurgie et politique en Afrique centrale. Deux mille ans de vestiges sur les plateaux Batéké. Gabon, Congo, Zaïre. Paris: Karthala.

Ervedosa, C. (1980). Arqueologia Angolana. Lisboa: Edições 70.

Esteves, E. (1989). Mbanza Kongo, ville archéologique. Nsi, 6, 159-164.

Fleisher, J. B. (2010). Swahili synoecism: Rural settlements and town formation on the central East African coast, A.D. 750-1500. Journal of Field Archaeology, 35(3), 265-282.

Fleisher, J. B., \& Wynne-Jones, S. (2012). Finding meaning in ancient Swahili spatial practices. African Archaeologial Review, 29(2/3), 171-207.

Fletcher, R. J. (1995). Limits of settlement growth: Theoretical outline. Cambridge: Cambridge University Press.

Fletcher, R. J. (1998). African urbanism: Scale, mobility and transformations. In G. Connah (Ed.), Transformations in Africa: Essays on Africa's later past (pp. 104-138). London: Leicester University Press.

Freund, B. (2007). The African city: A history. Cambridge: Cambridge University Press.

Fromont, C. (2011). Dance, image, myth, and conversion in the kingdom of the Kongo, 1500-1800. African Arts, 44, 52-63.

Grégoire, C. (1976). Le champ sémantique du thème bantu *-bánjá. African Languages/Langues Africaines, 2, 1-12.

Guttierez, M. (2008). Recherches archéologiques en Angola: Préhistoire, art rupestre, archéologie funéraire. Paris: L'Harmattan.

Heimlich, G. (2010). Lower Congo rock art revisited. Nyame Akuma, 74, 42-50.

Heimlich, G. (2013). Rock art as a source for the history of the Kongo kingdom. In S. Cooksey, R. Poynor, \& H. Vanhee (Eds.), Kongo across the waters (pp. 34-37). Gainesville: University Press of Florida.

Heywood, L. M. (2009). Slavery and its transformation in the kingdom of Kongo: 1491-1800. Journal of African History, 50(1), 1-22.

Hilton, A. (1985). The kingdom of Kongo. Oxford; New York: Clarendon Press; Oxford University Press.

Huffman, T. N. (2005). Mapungubwe: Ancient African civilization on the Limpopo. Johannesburg: Wits University Press.

Jadin, L. (1964). Le clergé séculier et les capucins du Congo et d'Angola aux XVIe et XVIIe siècles: Conflits de juridiction, 1700-1726. Bruxelles: Academia Belgica.

Jadin, L. (1968). Relations sur le Congo et l’Angola tirées des archives de la Compagnie de Jésus 1621-1631. Bruxelles: Academia Belgica.

Jansson, J. (1650). Regna Congo et Angola [map]. Amsterdam.

Janszoon, W. B. (1608). Africa [map]. Amsterdam.

Kanimba Misago, C. (1991). L’Age du Fer Ancien : Zaïre. In R. Lanfranchi \& B. Clist (Eds.), Aux origines de l'Afrique centrale (pp. 212-217). Libreville: Centres Culturels Français d'Afrique Centrale, CICIBA.

Kusimba, C., Kusimba, S. B., \& Agbaje-Williams, B. (2006). Precolonial African cities: Size and density. In G. R. Storey (Ed.), Urbanism in the preindustrial world: Cross-cultural approaches (pp. 145-158). Tuscaloosa: The University of Alabama Press. 
Ladmirant, H., \& Annaert, A. (1970). Carte géologique du Congo. Feuille Inkisi S.6/15. Bruxelles: Institut Géographique Militaire de Belgique.

Laman, K. E. (1936). Dictionnaire kikongo-français, avec une étude phonétique décrivant les dialectes les plus importants de la langue dite kikongo. Bruxelles: Librairie Falk.

Laman, K. E. (1957). The Kongo II. Uppsala: Almqvist \& Wiksells.

Lanfranchi, R. (1991). L'Age du Fer Ancien : Congo. In R. Lanfranchi \& B. Clist (Eds.), Aux origines de l'Afrique centrale (pp. 208-211). Libreville: Centres Culturels Français d'Afrique Centrale, CICIBA.

Lanfranchi, R., \& Clist, B. (Eds.). (1991). Aux origines de l'Afrique Centrale. Libreville: Centres Culturels Français d'Afrique Centrale, CICIBA.

Lanfranchi, R., \& Pinçon, B. (1988). Résultats préliminaires des prospections archéologiques récentes sur les plateaux et collines Teke en République Populaire du Congo (1984-1987). Nsi, 3, 24-31.

LaViolette, A. (2013). The Swahili world. In P. Mitchell \& P. Lane (Eds.), Oxford handbook of African archaeology (pp. 901-914). Oxford: Oxford University Press.

LaViolette, A., \& Fleisher, J. B. (2005). The archaeology of sub-Saharan urbanism: Cities and their countrysides. In A. B. Stahl (Ed.), African archaeology: A critical introduction (pp. 327-352). Malden: Blackwell.

Loir, H. (1935). Le tissage du raphia au Congo belge. Tervuren: Musée du Congo belge.

MacGaffey, W. (2002). Twins, Simbi spirits, and Lwas in Kongo and Haiti. In L. M. Heywood (Ed.), Central Africans and cultural transformations in the American diaspora (pp. 211-226). Cambridge: Cambridge University Press.

Magnavita, C., Breunig, P., Ameje, J., \& Posselt, M. (2006). Zilum: A mid-first millennium BC fortified settlement near Lake Chad. Journal of African Archaeology, 4(1), 153-169.

Marcus, J., \& Sabloff, J. A. (2008). The ancient city: New perspectives on urbanism in the Old and New World. Santa Fe: School for Advanced Research Press.

McIntosh, S. K. (1999). Modeling political organization in large-scale settlement clusters: A case study from the Inland Niger Delta. In S. K. McIntosh (Ed.), Beyond chiefdoms: Pathways to complexity in Africa (pp. 66-79). Cambridge: Cambridge University Press.

McIntosh, R. J. (2005). Ancient Middle Niger: Urbanism and the self-organizing landscape. Cambridge: Cambridge University Press.

Mertens, J. (1942). Les chefs couronnés chez les Ba Kongo orientaux : Etude de régime successoral. Bruxelles: G. van Campenhout.

Monroe, C. J. (2007). Continuity, revolution, or evolution on the Slave Coast of West Africa? Royal architecture and political order in pre-colonial Dahomey. Journal of African History, 48(3), 349-373.

Monroe, C. J. (2013). The archaeology of the precolonial state in Africa. In P. Mitchell \& P. Lane (Eds.), Oxford handbook of African archaeology (pp. 703-722). Oxford: Oxford University Press.

Mortelmans, G. (1962). Archéologie des grottes Dimba et Ngovo (région de Thysville, Bas-Congo). In G. Mortelmans \& J. Nenquin (Eds.), Actes du IVe Congrès Panafricain de Préhistoire et de l'Etude du Quaternaire, 1959, Léopoldville (pp. 407-425). Tervuren: Musée royal de l'Afrique centrale.

Newstead, S. (2008). Merida no more: Portuguese redware in Newfoundland. PhD thesis, Memorial University Newfoundland, St John's.

Nikis, N., de Maret, P., Lanfranchi, R., Nsania, J., Goma, J.-P., Clist, B., \& Bostoen, K. (2013). Projet KongoKing. Prospections en République du Congo (Brazzaville) : Le cuivre et l'origine des anciens royaumes Kongo et Teke. Nyame Akuma, 80, 32-42.

Nothomb, J. (Ed.). (1931). La pratique missionnaire des PP. Capucins Italiens dans les royaumes de Congo, Angola et contrées adjacentes brièvement exposée pour éclairer et guider les missionnaires destinés à ces saintes missions. Louvain: Editions de l'AUCAM.

Philips, J. E. (1983). African smoking and pipes. Journal of African History, 24(3), 303-319.

Piazza, C. (Ed.). (1976). La prefettura apostolica del Congo alla metà del XVII secolo. La relazione inedita di Girolamo da Montesarchio. Milano: Dott. A. Giuffrè, Università di Trieste.

Pierot, F. (1987). Etude ethnoarchéologique du site de Mashita Mbanza (Zä̈re). Mémoire de licence, Université libre de Bruxelles.

Pigafetta, F. (1591). Relatione del reame di Congo et delle circonvcine contrade tratta delli scritti e ragionamenti di Odoardo Lopez, portoghese. Roma: B. Grassi.

Pikirayi, I. (2013). The Zimbabwe culture and its neighbours. Origins, development, and consequences of social complexity in southern Africa. In P. Mitchell \& P. Lane (Eds.), Oxford handbook of African archaeology (pp. 915-927). Oxford: Oxford University Press.

Pinçon, B. (1988). Archéologie du fleuve Congo : Prospections sur la rive droite entre l'Alima et le Stanley Pool (République Populaire du Congo). Nsi, 4, 3-9.

Pinçon, B. (1991). L'archéologie du royaume Teke. In R. Lanfranchi \& B. Clist (Eds.), Aux origines de l'Afrique centrale (pp. 243-252). Libreville: Centres Culturels Français d'Afrique Centrale, CICIBA. 
Posnansky, M. (1968). The excavation of an Ankole capital site at Bweyorere. Uganda Journal, 32(2), 165-182. Rainero, R. (Ed.). (1972). Congo agli inizi del settecento nella relazione di P. Luca da Caltanisetta. Firenze: La Nuova Italia.

Randles, W. G. L. (1968). L'ancien royaume du Congo des origines à la fin du XIXe siècle. Paris; La Haye: Mouton. Rochette, D. (1989). Etude du site archéologique de Kingabwa (Kinshasa, Zä̈re). Mémoire de licence, Université libre de Bruxelles.

Saccardo, G. P. (1982). Congo e Angola con la storia dell'antica missione dei cappuccini (Vol. I). VeneziaMestre: Curia Provinciale dei Cappuccini.

Schoeman, A. (2013). Southern African late farming communities. In P. Mitchell \& P. Lane (Eds.), Oxford handbook of African archaeology (pp. 928-941). Oxford: Oxford University Press.

Schwartz, D., \& Lanfranchi, R. (1990). Les remaniements de sols sur sables Bateke dans la région de Brazzaville (Congo). Une mise au point. In R. Lanfranchi \& D. Schwartz (Eds.), Paysages quaternaires de l'Afrique centrale atlantique (pp. 167-182). Paris: ORSTOM.

Sengeløv, A. (2014). Mbele a lulendo: Een studie naar de herkomst en context van de zwaarden gevonden op het grafveld te Kindoki, Mbanza Nsundi, Bas-Congo. M.A. thesis, Universiteit Gent, Gent.

Sinclair, P. (2013). The archaeology of African urbanism. In P. Mitchell \& P. Lane (Eds.), Oxford handbook of African archaeology (pp. 689-702). Oxford: Oxford University Press.

Souindoula, S. (1992). Mbanza Soyo: Pesquisas arqueológicas. Leba, 7, 277-282.

Thornton, J. K. (1977). Demography and history in the Kingdom of Kongo, 1550-1750. Journal of African History, 18(4), 507-530.

Thornton, J. K. (1982). The Kingdom of Kongo, ca. 1390-1678. The development of an African social formation. Cahiers d'Études africaines, 22(87/88), 325-342.

Thornton, J. K. (1983). The Kingdom of Kongo: Civil war and transition, 1641-1718. Madison: University of Wisconsin Press.

Thornton, J. K. (1984). The development of an African Catholic church in the Kingdom of Kongo, 14911750. Journal of African History, 25(2), 147-167.

Thornton, J. K. (1990). Precolonial African industry and the Atlantic trade, 1500-1800. African Economic History, 19, 1-19.

Thornton, J. K. (2000). Mbanza Kongo/São Salvador: Kongo's holy city. In D. M. Anderson \& R. Rathbone (Eds.), Africa's urban past (pp. 67-84). Oxford: James Currey.

Thornton, J. K. (2001). The origins and early history of the Kingdom of Kongo, c.1350-1550. International Journal of African Historical Studies, 34(1), 89-120.

Valdeyron, N., \& Da Silva Domingos, S. L. (2009). Nouvelles données sur la préhistoire récente angolaise: Le gisement de Cabolombo à Benfica revisité. In Collectif (Ed.), De Méditerranée et d'ailleurs ... Mélanges offerts à Jean Guilaine (pp. 737-749). Toulouse: Archives d'écologie préhistorique.

Valdeyron, N., \& Da Silva Domingos, S. L. (2012). Coquillages (beaucoup) et crustacés (un peu): L'économie des populations littorales de la baie de Luanda (Angola), du début de notre ère jusqu'à la période actuelle. Palethnologie de l'Afrique, 4, 111-142.

Van Moorsel, H. (1948). Une industrie céramique ancienne dans la plaine de Léopoldville. Brousse, 3-4, 17-39.

Van Moorsel, H. (1968). Atlas de préhistoire de la plaine de Kinshasa. Kinshasa: Université Lovanium.

Van Noten, F. (Ed.). (1982). The archaeology of Central Africa. Graz: Akademische Druck- und Verlaganstalt.

Van Wing, J. (1921). Etudes Bakongo. Histoire et sociologie. Bruxelles: Goemare.

Van Wing, J. (1938). Etudes Bakongo. II. Religion et magie. Bruxelles: Librairie Falk fils.

Vandenhoute, J. (1973). De Begraafplaats van Ngongo-Mbata (Neder-Zaire). Licentiaatverhandeling, Rijksuniversiteit Gent.

Vansina, J. (1990). Paths in the rainforest: Toward a history of political tradition in Equatorial Africa. Madison: University of Wisconsin Press.

Vansina, J. (1994). Raffia cloth in West Central Africa, 1500-1800. In M. F. Mazzaoui (Ed.), Textiles: Production, trade, and demand (pp. 263-281). Aldershot: Ashgate Publishing.

Vansina, J. (1999). Pathways of political development in Equatorial Africa and neo-evolutionary theory. In S. K. McIntosh (Ed.), Beyond chiefdoms: Pathways to complexity in Africa (pp. 166-172). Cambridge: Cambridge University Press.

Verhaeghe, C. (2014). Funeraire rituelen in het Kongo Koninkrijk: de betekenis van schelp-en glaskralen in de begraafplaats van Mbanza Nsundi, Neder-Congo. M.A. thesis, Universiteit Gent.

Walford, T., \& Massey, R. (Eds.). (2007). Creamware and pearlware re-examined. Beckenham: English Ceramic Circle.

Wamuini Lunkayilakio, S., Vreven, E., Vandewalle, P., Mutambue, S., \& Snoeks, J. (2010). Contribution to the knowledge of the ichthyofauna in the Inkisi River, Lower Congo (RDC). Cybium, 34(1), 83-91.

Weeks, J. H. (1914). Among the primitive Bakongo. New York: Negro Universities Press. 